\title{
ZE STUDIÓW NAD POCZĄTKAMI KULTURY ŁUŻYCKIEJ W ZACHODNIEJ WIELKOPOLSCE
}

\section{ON THE STUDIES OF THE BEGINNINGS OF THE LUSATIAN CULTURE IN WESTERN WIELKOPOLSKA}

\author{
Maciej Kaczmarek \\ Instytut Prahistorii, Uniwersytet im. Adama Mickiewicza \\ Św. Marcin 78, 61-809 Poznań, Poland
}

\begin{abstract}
The article is an attempt to explain the origin of the Lusatian culture in western Wielkopolska on the basis of available archaeological evidence. The author inscribes the major role in the formation of the early Lusatian groups in western Wielkopolska to communities from Lower Silesia. From this territory culture impulses radiated along the Odra river, which led to the emergence of the early assemblages of the Urnfield culture in western Wielkopolska and the Lubusz Lands at the beginning of phase III of the Bronze Age.
\end{abstract}

\section{UWAGI WSTĘPNE}

Dzisiejsze poglądy na genezę zachodniej strefy kultury łużyckiej są w dużej mierze modyfikacją wcześniejszych koncepcji J. Kostrzewskiego. Nadal przyjmuje się pierwszoplanową rolę kultury przedłużyckiej (mogiłowej) jako podstawowego substratu, na bazie którego u schyłku starszego okresu epoki brązu doszło do powstania nowej jakości kulturowej. Uwzględniając jednak nieco silniej udział elementów kultury trzcinieckiej, niejednorodny charakter śląsko-wielkopolskich ugrupowań mogiłowych (przedłużyckich) oraz oddziaływania środkowonaddunajskie, znacząco poszerzono spectrum czynników warunkujących proces kształtowania się kultury w typie pól popielnicowych na terenach dorzecza środkowej Odry. Zanegowano tym samym wcześniejsze sugestie o linearnej transformacji (ewolucji) kultury przedłużyckiej w łużycką. Zmianie uległa również ocena chronologii omawianych zjawisk kulturowych - część materiałów archeologicznych, zaliczanych niegdyś do schyłku kultury mogiłowej, zaczęto bowiem klasyfikować jako przynależne najwcześniejszej fazie kultury łużyckiej ${ }^{1}$.

\footnotetext{
'Gediga 1967, s. 180-183; 1982, s. 55; Gedl 1974a; 1991.
} 
Zagadnienie genezy kultury łużyckiej w zachodniej Wielkopolsce rozpatrywano zwykle łącznie $\mathrm{z}$ przebiegiem tych procesów na ziemi lubuskiej oraz w kontekście analogicznych przemian dokonujących się u progu środkowego okresu epoki brązu na Śląsku i na Łużycach. Różnice w poglądach poszczególnych badaczy dotyczyły głównie chronologii najwcześniejszych zespołów w typie pól popielnicowych, ich zasięgu przestrzennego oraz kierunków afiliacji.

J. Kostrzewski ${ }^{2}$ przyjmował, że do ukształtowania się kultury łużyckiej doszło na przełomie II i III EB niemal jednocześnie w całym dorzeczu środkowej Odry, a więc na Łużycach, na Dolnym Śląsku, ziemi lubuskiej i w zachodniej Wielkopolsce. Proces ów był wynikiem przeobrażeń kultury przedłużyckiej, przy współudziale elementów kultury trzcinieckiej. Tradycji tej ostatniej przypisywał początkowo wykształcenie się wczesnołużyckiego stylu guzowego. Wyróżniona przez J. Kostrzewskiego grupa zachodniowielkopolska zajmowała w III EB w sposób zwarty tylko ziemię lubuską i sąsiednie powiaty Wielkopolski: międzychodzki, nowotomyski, wolsztyński oraz zachodnią część powiatu kościańskiego. Pozostałe tereny omawianego obszaru tworzyły jedynie rozproszoną strefę najstarszych znalezisk „łużyckich".

Zdaniem M. Gedla ${ }^{3}$ kultura łużycka w zachodniej Wielkopolsce, na ziemi lubuskiej i w przyległych partiach wschodniej Brandenburgii ukształtowała się w ciagu III EB, najpewniej jednak dopiero w drugiej połowie tego okresu $\left(\mathrm{HaA}_{1}\right)$. Wyróżniona przez niego grupa brandenbursko-lubuska miała powstać przy wyraźnym udziale oddziaływań płynących ze strony grupy sasko-łużyckiej.

Za wcześniejszym datowaniem fazy wczesnołużyckiej na omawianym obszarze, odpowiadającym drugiej połowie II EB (BC), opowiedział się B. Gediga ${ }^{4}$. Zakładał on, że początki kształtowania się kultury łużyckiej zaznaczyły się jednocześnie w południowej części Śląska (Plaskowyż Głubczycki), na Dolnym Śląsku, a także na ziemi lubuskiej i w przyległych partiach Wielkopolski.

$\mathrm{Z}$ kolei A. Gardawski ${ }^{5}$, umieszczając zachodnią Wielkopolskę w ramach tzw. grupy dolnośląsko-wielkopolskiej, obejmującej ponadto Dolny Śląsk oraz nadodrzańską lewobrzeżną część Górnego Śląska, nie precyzował bliżej czasu rozpoczęcia procesu formowania się pierwszych zespołów popielnicowych. Nadmieniał jedynie, że elementem unifikującym te obszary do $\mathrm{HaA}_{1}$ jest styl guzowy w ceramice, będący również kryterium wyróżniającym lokalne podgrupy. Czynnikiem sprawczym, który doprowadził do wyksztalcenia się nowego oblicza kulturowego na wspomnianych terenach, miał być przede wszystkim szlak odrzański, będący swoistym pomostem pomiędzy Siedmiogrodem a Północą.

${ }^{2}$ Kostrzewski 1948, s. 211 n.; 1949, s. 90 n.; 1955, s. 95, 96, mapka 6; Kostrzewski, Chmielewski, Jażdżewski 1965, s. 148-150, ryc. 31.

${ }^{3}$ Gedl 1974 a, s. $40 ; 1975$ b, s. 36,$118 ; 1980$ c, s. $83,84$.

${ }^{4}$ Gediga 1977, s. 10.

${ }^{5}$ Gardawski 1979a, s. 47-49, 64-69, ryc. 16. 
Polemicznie względem poglądów A. Gardawskiego wypowiedział się na temat początków i rozwoju kultury łużyckiej w strefie środkowego Nadodrza A. Kołodziejski $^{6}$. W odniesieniu do ziemi lubuskiej i sąsiadujących z nią partii zachodniej Wielkopolski, autor ten ograniczył się tylko do zanegowania wcześniejszych sugestii M. Gedla, odnośnie znaczącej roli grupy sasko-łużyckiej w procesie formowania się tutejszych zespołów wczesnołużyckich. Brak większego znaczenia grupy saskołużyckiej w omawianej kwestii podkreślał także A. Marcinkian ${ }^{7}$.

Wreszcie M. Kwapiński ${ }^{8}$, analizując ornamentykę guzową ceramiki wczesnołużyckiej, sugerował, że powstanie kultury łużyckiej w całym dorzeczu środkowej Odry było końcowym etapem wielofazowego procesu akulturacji społeczeństw zamieszkujących te obszary od początków epoki brązu. Zakładając, zgodnie z ustaleniami tego autora, iż ornament guzowy typu $\mathrm{D}_{1}$ można datować już na koniec II EB (BC), należałoby przyjąć, że właśnie wtedy pojawiły się najwcześniejsze zespoły „łużyckie” w zachodniej Wielkopolsce, co jednak nie wydaje się być w pełni uzasadnione.

\section{ŚRODOWISKO KULTUROWE ZACHODNIEJ WIELKOPOLSKI WE WCZESNYM OKRESIE EPOKI BRĄZU}

Przez blisko 14 stuleci, bo od początków epoki brązu aż po młodszy okres przedrzymski, zachodnia Wielkopolska, wespół ze Śląskiem i północno-zachodnią Małopolska, stanowiła część szerszej strefy kulturowej, inspirowanej przede wszystkim przez oddziaływania płynące $z$ dorzecza środkowego Dunaju ${ }^{9}$. Świt epoki brązu na omawianym obszarze, który przyczynowo należy wiązać z pojawieniem się czeskosasko-śląskiej prowincji kultury unietyckiej, nie rysuje się w chwili obecnej zbyt ostro. Najprawdopodobniej dopiero w czasach odpowiadających $\mathrm{BA}_{2}$ tereny leżące w dorzeczu środkowej i dolnej Warty zostały włączone do kręgu tzw. środkowoeuropejskiej cywilizacji wczesnobrązowej, dzięki uformowaniu się w południowozachodniej Wielkopolsce (nad środkową Obrą i dolną Mogilnica) mikroregionu osadniczego ludności kultury unietyckiej, związanego z grupą śląsko-wielkopolską. Jest on reprezentowany m.in. przez znane cmentarzysko kurhanowe w Łękach Małych, pow. Grodzisk Wielkopolski ${ }^{10}$, tutaj odkryto także grupę skarbów brązowych typu Głogów charakterystycznych dla klasycznej fazy kultury unietyckiej ${ }^{11}$. Zapewne $z$ tym okresem wiąże się również pierwsza faza zabudowy słynnej już osady

\footnotetext{
${ }^{6}$ Kołodziejski 1980, s. 101, 102.

${ }^{7}$ Marcinkian 1986, s. 106.

${ }^{8}$ Kwapiński 1985, s. 38.

${ }^{9}$ Bukowski 1983, s. 19 n.

${ }^{10}$ Kowiańska-Piaszykowa, Kurnatowski 1954.

${ }^{11}$ Blajer 1990a, s. 84, 85, 111, 112, 114, 125-127, ryc. 2, tabl. XXXII-XXXVII, XLV, LXXV,
} LXXX, 
wczesnobrazowej w Bruszczewie, pow. Kościan, stan. 5, z której materiał archeologiczny ciagle pozostaje nie opracowany ${ }^{12}$.

Dotychczas nie stwierdzono natomiast śladów stabilnego osadnictwa unietyckiego z fazy klasycznej w znacznej części zachodniej Wielkopolski (na północ od środkowej Obry), co pozwala zakładać, że była ona raczej strefą penetracyjną dla ludności tej kultury. Związek tych terenów z „centrami” unietyckimi na Śląsku i w południowo-zachodniej Wielkopolsce dokumentują tylko liczne skarby wyrobów brązowych typu Głogów, zlokalizowane niemal wyłącznie w strefie lewego dorzecza środkowej Warty. Podobnie jak wspomniane powyżej depozyty ze skupiska nadobrzańskiego, zawierają one wytwory charakterystyczne dla klasycznej fazy kultury unietyckiej $\left(\mathrm{BA}_{2}\right)$, a więc przede wszystkim ozdoby obręczowe i siekierki. Znacznie rzadziej spotyka się okazałe sztylety i berla sztyletowe, nawiązujące do egzemplarzy wchodzących w skład wyposażenia grobów „książęcych” odkrytych w Łękach Małych ${ }^{13}$. Bez jednoznacznej odpowiedzi trzeba obecnie pozostawić pytanie o północny zasięg śląsko-wielkopolskiej grupy kultury unietyckiej. Wynika to $\mathrm{z}$ bieżącego stanu badań, a także niejasności taksonomicznych związanych $\mathrm{z}$ wydzielaniem tzw. kultury grobsko-śmiardowskiej (por. niżej).

Zmierzch wczesnego okresu epoki brązu, który nastapił w $\mathrm{BA}_{2} / \mathrm{BB}_{1}-\mathrm{BB}_{1}$, będący skutkiem szerszych przemian kulturowych dokonujących się wówczas w Kotlinie Karpackiej, przyniósł też powolny zanik ugrupowań z kulturą unietycką oraz wzmożenie oddziaływań południowych, określanych jako tzw. wpływy madziarowskowieterzowskie. Zdaniem Z. Bukowskiego ${ }^{14}$ w odniesieniu do zachodniej strefy ziem polskich należy przyjmować, że były to przede wszystkim wpływy wieterzowskie, które objęły swoim zasięgiem Śląsk, Łużyce, dochodząc do południowo-zachodniej Wielkopolski, a nawet przekraczając zwarty zasięg dotychczasowego osadnictwa unietyckiego. Najwymowniejszym ich wyrazem było fortyfikowanie osad, zwiazane zapewne $\mathrm{z}$ rozwojem hodowli w bezpośrednim sąsiedztwie zagród. Ze zjawiskiem tym mamy do czynienia na wspomnianej już osadzie w Bruszczewie, stan. $5^{15}$.

Położone nieco dalej na pólnoc od dorzecza środkowej Obry tereny zachodniej Wielkopolski nie noszą już tak wyraźnych śladów oddziaływań wieterzowskich, choć badacze bardzo często zwracają uwagę na podobną zapewne w charakterze osadę obronną (?) ze Słopanowa w powiecie szamotulskim, zniszczoną przez późniejsze osadnictwo z okresu wpływów rzymskich ${ }^{16}$. Przyjmuje się, że egzystowały tutaj późne grupy kultury unietyckiej, na co zdają się wskazywać nieliczne pochów-

${ }^{12}$ M.in. Pieczyński 1970; Gedl 1982, s. 421; Bukowski 1980, s. 297; 1983, s. 28; Klosińska 1997. s. 104.

${ }^{13}$ Blajer 1990a, s. 83, 85, 102, 103, 113, 122, 139-141, ryc. 2, tabl. VIII, XLIV, LXII, CXIII: 3-5, CXIV, CXV, CXVII: 4, 5; Kłosińska 1997, s. 133.

${ }^{14}$ Bukowski 1980, s. 288-292; 1983, s. 28.

${ }^{15}$ Kłosińska 1997, s. 134.

${ }^{16}$ Kłosińska 1997, s. 134. 
ki szkieletowe, jak choćby grób $50 \mathrm{z}$ cmentarzyska w Gorszewicach ${ }^{17}$, w którym znaleziono 2 szpile o kulistych, ukośnie przekłutych główkach, datowane na późną (VI) fazę tej kultury. Z kolei północna część zachodniej Wielkopolski, głównie zaś tereny położone $w$ widłach Warty i Noteci, objęta była osadnictwem tzw. kultury grobsko-śmiardowskiej, wokół której narosło sporo kontrowersji w literaturze przedmiotu. Stało się to $w$ dużej mierze za sprawą publikacji sztandarowych dla poznania tej kultury cmentarzysk w Skrzatuszu i Śmiardowie ${ }^{18}$. Nie wdając się w bliższą charakterystykę poglądów poszczególnych badaczy, co nie jest przecież celem tego artykułu, wypada podkreślić głosy podważające w ogóle zasadność wydzielania tej jednostki taksonomicznej. Ponieważ problem ów daleki jest na razie od przynajmniej częściowego rozstrzygnięcia, pozostaje przyjąć za Z. Bukowskim ${ }^{19}$, iż północną część zachodniej Wielkopolski zajmowały we wczesnym okresie epoki brązu „bliżej dotąd nie zdefiniowane zespoły kulturowe, określane tradycyjnie jako kultura grobsko-śmiardowska". Niektórzy badacze postulują nawet, aby do czasu lepszego rozpoznania problematyki początków epoki brązu w tym regionie posługiwać się umownym terminem „kultura grobska”20. Niewątpliwie z zasięgiem owej kultury, pozostającej pod wyraźnym wpływem unietyckiego ośrodka metalurgicznego, winno się łączyć większą część wspomnianych wyżej depozytów typu Glogów, zgrupowanych w dorzeczu środkowej Warty.

Nieco odmienny trend przemian kulturowych na przestrzeni wczesnego okresu epoki brązu obserwujemy natomiast na ziemi lubuskiej i na sąsiadujących z nią rubieżach zachodniej Wielkopolski. Tereny te weszły niewątpliwie w strefę zwartego zasięgu kultury unietyckiej, której lokalną odmianą była tzw. grupa (faza) lubuska. Grupa ta ukształtowała się jednak dopiero pod koniec $\mathrm{BA}_{2}$, lub nawet w początkach $\mathrm{BB}_{1}$, pod wpływem docierających tutaj niemal jednocześnie impulsów ze strony późnej kultury unietyckiej oraz wczesnych ugrupowań mogiłowych na Śląsku ${ }^{21}$. Najbardziej charakterystyczne materiały grupy lubuskiej pochodzą z nielicznych inwentarzy grobowych, odkrytych na cmentarzyskach w Grobi I, pow. Międzychód $^{22}$ i w Swarzynicach, pow. Zielona Góra ${ }^{23}$. W obrębie obu tych stanowisk znajdowały się także późniejsze pochówki ludności kultury łużyckiej. Niewykluczone zatem, że społeczności grupy lubuskiej egzystowały aż do chwili wyodrębnienia się na tych terenach pierwszych zespołów kultury łużyckiej. Wydaje się to całkiem prawdopodobne, już choćby ze względu na nikłą frekwencję materiałów mogiło-

${ }^{17}$ Knapowska-Mikołajczykowa 1957, s. 39, 40, ryc. 22.

${ }^{18}$ Schäfer 1987. Por. też szereg głosów dyskusyjnych w związku z tą pracą: Wierzbicki 1992; Bokiniec, Czebreszuk 1993 oraz ostatnie uwagi Z. Bukowskiego (1998, s. 19, 104, 105).

${ }^{19}$ Bukowski 1998, s. 19.

${ }^{20}$ Blajer 1990a, s. 83.

${ }^{21}$ Kwapiński 1985, s. 10.

${ }^{22}$ Knapowska-Mikołajczykowa 1957, s. 44-46, ryc. 29-33.

${ }^{23}$ Sarnowska 1969, s. 349-351, ryc. 160. 
wych na tym obszarze. Szczególną uwagę w tym kontekście należałoby zwrócić na stanowiska grupy lubuskiej położone w okolicach Swarzynic, Międzyrzecza, Międzychodu i Gorzowa Wlkp. Tam bowiem w środkowym okresie epoki brązu powstały najwcześniejsze zespoły z ceramiką guzową (ryc. 2).

Pomimo dość mglistego obrazu stosunków kulturowych, jakim dysponujemy dla zachodniej Wielkopolski u zarania epoki brązu, stosunkowo wyraźnie rysują się pewne różnice mikroregionalne, widoczne tutaj także później, w dobie rozwoju kultury łużyckiej. Uderzająca jest zwłaszcza większa aktywność kulturowa terenów leżących po obu stronach środkowego biegu Obry ${ }^{24}$. Przejawia się to wykształceniem stabilnej struktury osadniczej (przynajmniej od fazy $\mathrm{BA}_{2}$ ), a także powiązaniami z unietyckimi centrami na Śląsku i w Czechach. Na tym tle pozostałe ziemie zachodniowielkopolskie wypadają raczej niekorzystnie, tworząc rozległą peryferię, selektywnie recypującą unietyckie wzorce kulturowe.

\section{ZACHODNIA WIELKOPOLSKA W ZASIĘGU KULTURY PRZEDLUŻYCKIEJ}

Wraz ze schyłkiem oddziaływań madziarowsko-wieterzowskich, który przypadł na rozwinięty $\mathrm{BB}_{1}$, w zachodniej strefie ziem polskich rozpoczął się powolny zanik ugrupowań późnounietyckich, któremu czasowo odpowiada pojawianie się pierwszych stanowisk (głównie cmentarzysk) związanych z ludnością kultury mogiłowej. Przyjmuje się, że zmiana oblicza kulturowego obszarów położonych w dorzeczu górnej i środkowej Odry miała związek $\mathrm{z}$ napływem znacznych grup ludności z Południa, która wykorzystując dawne szlaki handlowe docierała tutaj głównie przez Bramę Morawską. Wśród badaczy brak jednak zgody co do charakteru, wielkości, a także zasięgu owych migracji w kontekście kształtującej się w początkach II EB $\left(\mathrm{BB}_{1}\right)$ kultury przedłużyckiej, będącej lokalną, śląsko-wielkopolską odmianą kultury mogiłowej. Różnie bywa też interpretowany zasięg oraz zróżnicowanie wewnętrzne owej kultury, choć niewątpliwie zespół ów już od dawna jawi się jako niejednolity wewnętrznie ${ }^{25}$.

W zachodniej Wielkopolsce odkryto do tej pory 142 stanowiska (w obrębie 106 miejscowości), które można wiązać ze starszym okresem epoki brązu (ryc. 1). Zdecydowanie dominują wśród nich znaleziska fragmentów ceramiki, pozyskane z powierzchni ziemi bądź z wypełnisk obiektów młodszych chronologicznie. Stanowiska takie często nieco „na wyrost” traktowane są jako pozostałości osad. Przy braku większej liczby zachowanych całych form naczyń za cechy dystynktywne rozdrobnionego materiału ceramicznego, będacce podstawą identyfikacji kulturowej, przyjmuje się zwykle charakterystyczne odmiany ornamentacji: chropowacenie ze-

${ }^{24}$ Kłosińska 1992a, ryc. 1, 4.

${ }^{25}$ M.in. Gedl 1975a, s. 79-82; Gediga 1977, s. 9; 1978, s. 165; Bukowski 1980, s. 292, 293; 1983, s. 30,31 . 
wnętrznych partii ścian naczyń odciskami tekstylnymi lub pseudotekstylnymi, zdobienie brzuśca gęsto rytymi pionowymi żłobkami oraz umieszczanie poniżej krawędzi wylewu dookolnych listew plastycznych. Ornament plastyczny znany jest w dwóch podstawowych odmianach, a mianowicie gładkiej, daszkowatej listwy - powszechnie kojarzonej ze środowiskiem kultury trzcinieckiej, oraz listwy z dołkami palcowymi - spotykanej głównie w tzw. strefie przemieszania ${ }^{26}$. Ze wspomnianych wyżej sposobów chropowacenia powierzchni przede wszystkim zdobnictwo „tekstylne" i ,pseudotekstylne" uznaje się niemal wyłącznie za atrybut kultury przedłużyckiej, co w świetle ostatnich badań nie wydaje się być już tak pewne. Ornament ów, nie spotykany w inwentarzach innych kultur mogiłowych, występuje także na naczyniach zupełnie obcych kulturze przedłużyckiej, przypisywanych m.in. kulturze unietyckiej, trzcinieckiej (!), a nawet łużyckiej. Jego geneza sięga nawet wczesnego okresu epoki brązu. Większość starszobrązowych stanowisk ,ceramicznych” z zachodniej Wielkopolski, nierzadko datowanych tak właśnie na podstawie obecności wspomnianego ornamentu, łączy się jednak z kulturą przedłużycką. Zalicza się do niej także zespoły, w których pojawiły się elementy określane tradycyjnie jako trzcinieckie (gładka dookolna listwa plastyczna, facetowanie krawędzi) ${ }^{27}$. Zjawiskọ przenikania cech trzcinieckich w obręb strefy mogiłowej, mimo iż nie powinno stanowić podstawy daleko idących wniosków o przesunięciu zachodniej granicy tego ugrupowania kulturowego, zwykle jest skrupulatnie akcentowane przez badaczy. Znalazło to również wyraz na kartogramie stanowisk datowanych na II EB (ryc. 1).

Kolejną, stosunkowo liczną grupa stanowisk starszobrązowych w zachodniej Wielkopolsce są bezkontekstowe, pojedyncze znaleziska, najczęściej wyrobów brązowych typowych dla stylistyki kultury przedłużyckiej. Specjalne miejsce zajmuja natomiast depozyty brązowe, zawierające obok wytworów ,czysto” mogiłowych także formy, których dyspersja wykracza poza zwarty zasięg przestrzenny kultury przedłużyckiej (np. naramienniki z tarczkami spiralnymi). Łącznie odkryto 5 skarbów, w większości datowanych na schyłek II EB, w których dominowały ozdoby obręczowe.

Sporadycznie rejestrowane w międzyrzeczu środkowej Warty i Obry cmentarzyska mogiłowe (6) ustępują liczebnie nie tylko nekropoliom śląskim, ale też i południowowielkopolskim. Ich nikły stopień rozpoznania sprawia, że niewiele można obecnie powiedzieć na temat obrządku pogrzebowego praktykowanego przez ludność zachodniej Wielkopolski w starszym okresie epoki brązu.

W zachodniej Wielkopolsce zdecydowana większość stanowisk kultury przedłużyckiej zlokalizowana jest w bliskim sąsiedztwie największych arterii wodnych Warty, Noteci i Obry (ryc. 1). Przy tym najwyraźniej kształtuje się skupisko po obu stronach środkowej Warty, od kolana śremskiego po ujście Wełny, oraz koncentracja w rejonie środkowej Obry, w okolicach ujścia mniejszych cieków: Samicy i Mogilnicy. Interesujące, że tam też najbardziej widoczne jest nasycenie elementami trzci-

\footnotetext{
${ }^{26}$ Gedl 1975a, s. 62; Gediga 1978, s. 159, 160; Klosińska 1997, s. 44-48, ryc. 8.

${ }^{27}$ Kłosińska 1997, s. 46, 47, ryc. 9.
} 
nieckimi. Nieco mniejsze natężenie punktów osadniczych obserwujemy w dolinie dolnej Noteci oraz w strefie Obniżenia Obrzańskiego. Śladów osadnictwa starszobrązowego nie stwierdzono natomiast na rozległym obszarze Wału LwóweckoRakoniewickiego i Równiny Opalenickiej, a także w międzyrzeczu Warty i Noteci, na wysokości Czarnkowa i Chodzieży.

Nawiązując do trójstopniowego podziału kultury przedłużyckiej ${ }^{28}$, zachodniowielkopolskie „znaleziska mogiłowe” uporządkować można w ramach 3 podstawowych faz chronologicznych.

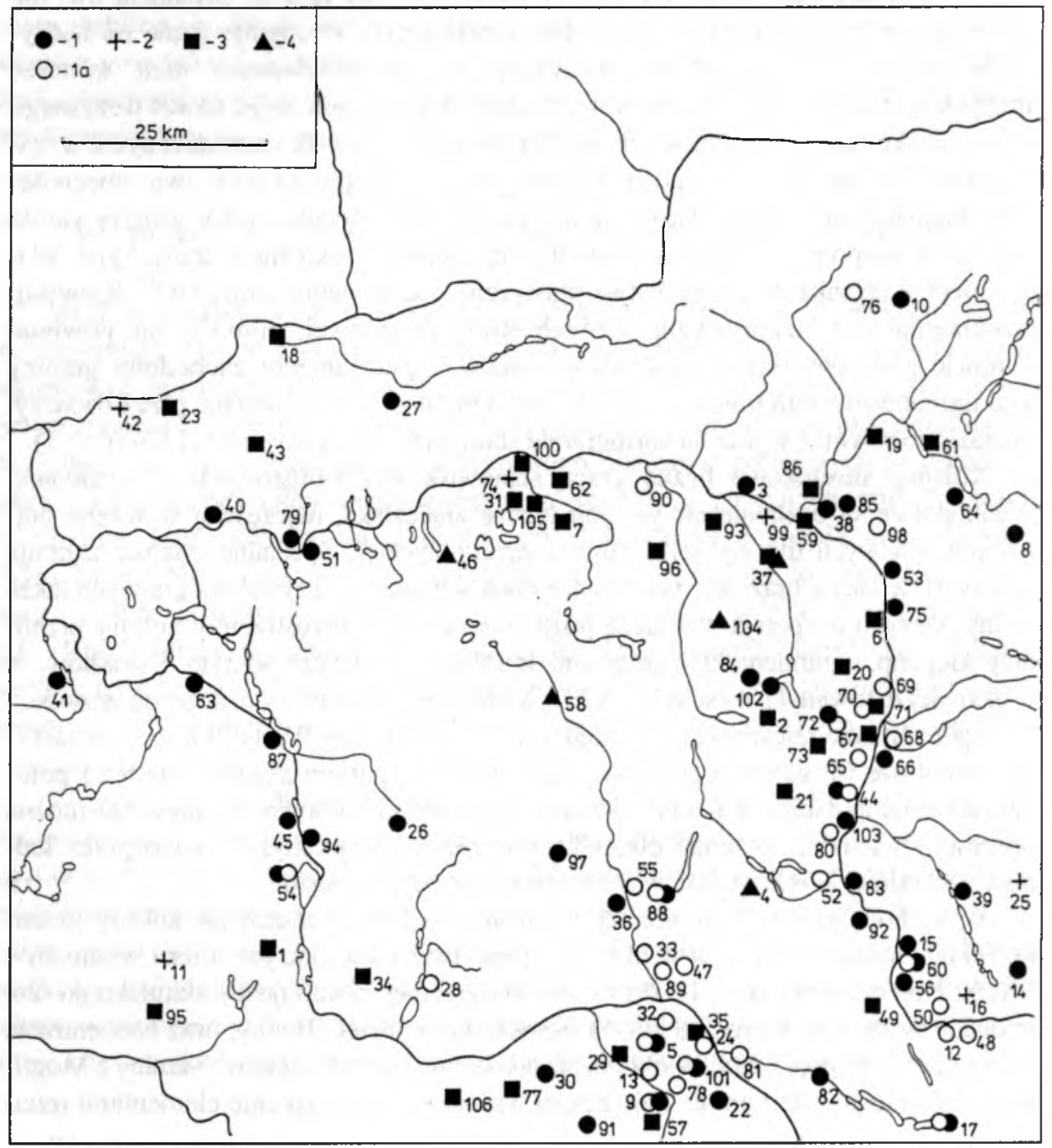

${ }^{28}$ Gedl 1975a, s. $72-76 ; 1992$, s. $41-47$, Taf. 1. 
Faza starsza kultury przedłużyckiej, datowana na $\mathrm{BB}_{1}$ (początki II EB), w zachodniej Wielkopolsce nie jest w zasadzie reprezentowana. $Z$ dużymi zastrzeżeniami można by z nią wiązać dwa bezkontekstowe znaleziska szpil brązowych z półkulistą główka, zaliczanych do odmiany Wojdal (Gniewowo - nr 22; Manieczki $\mathrm{nr} 49)^{29}$. Ponieważ szpile z półkulistą główką odmiany Wojdal występują również w klasycznej fazie kultury przedłużyckiej (tak też datowany jest eponimiczny zespół z Kujaw), niewykluczone więc, że i egzemplarze zachodniowielkopolskie pochodzą dopiero z połowy II $\mathrm{EB}^{30}$.

\section{Ryc. 1. Rozmieszczenie stanowisk ze starszego okresu epoki brązu w zachodniej Wielkopolsce}

Fig. 1. Distribution of the pre-Lusatian culture sites in western Wielkopolska

1 - Babimost, pow. zielonogórski, woj. lubuskie; 2 - Baranowo, pow. poznański, stan. 3; 3 - Bąblin, pow. obornicki, stan. 3; 4 - Będlewo, pow. poznański; 5 - Białcz, pow. kościański, stan. 27, 28 oraz nieoznaczone; 6 - Biedrusko, pow. poznański; 7 Binino, pow. szamotulski; 8 - Bliżyce, pow. wagrowiecki, stan. 2; 9 - Bruszczewo, pow. kościański, stan. $5,17,18 ; 10$ Budzyń, pow. chodzieski, stan. 3; 11 - Buków, pow. zielonogórski, woj. lubuskie; 12 - Bystrzek, pow. śremski, stan. 2, 5; 13 Czacz, pow. kościański, stan. 3, 4, 17; 14 - Czamotki, pow. średzki, stan. 2; 15 - Czmoniec, pow. poznański, stan. 1, 2; 16 Dąbrowa, pow. śremski; 17 - Dolsk, pow. śremski, stan. 5, 7; 18 - Drezdenko, pow. strzelecko-drezdenecki, woj. lubuskie; 19 - Garbatka, pow. obomicki, stan. 1; 20 - Glinienko, pow. poznański; 21 - Gluchowo, pow. poznański; 22 - Gniewowo, pow. kościański, stan. 3; 23 - Goszczanowiec, pow. strzelecko-drezdenecki, woj. lubuskie; 24 - Gurostowo, pow. kościański, stan. 8; 25 - Januszewo, pow. średzki, stan. 1; 26 - Jastrzębsko Stare, pow. nowotomyski; 27 - Kaczeniec, pow. czarnkowskoIrzcianecki, stan. 2; 28 - Karpicko, pow. wolsztyński, stan. 1; 29 - Karśnice, pow. kościański; 30 - Kluczewo, pow. wolsztyński, stan. 19; 31 - Klodzisko, pow. szamotulski; 32 - Kokorzyn, pow. kościański, stan. 27, 43, 49, 51; 33 - Konojad, pow. grodziski, stan. 5; 34 - Kopanica, pow. wolsztyński; 35 - Kościan; 36 - Kotowo, pow. grodziski, stan. 1; 37 - Kowalewko, pow, obornicki, stan. 3, 6; 38 - Kowanówko, pow. obornicki, stan. 12; 39 - Kórnik-Bnin, pow. poznański, stan. 7; 40 Krobielewko, pow. międzyrzecki, woj. lubuskie; 41 - Kursko, pow. międzyrzecki, woj. lubuskie; 42 - Lipki Male, pow. gorzowski, woj. lubuskie; 43 - Lubiatów, pow. strzelecko-drezdenecki, woj. lubuskie; 44 - Luboń, pow. poznański, stan. 4, 10. 13, 18, 27, 35, H oraz nieoznaczone; 45 - Lutol Mokry, pow. międzyrzecki, woj. lubuskie, stan. 2; 46 - Lutomek, pow. międzychodzki, stan. 22; 47 - Łagiewniki, pow. kościański, stan. 20; 48 - Łążek, pow. śremski; 49 - Manieczki, pow. śremski; 50 - Mechlin, pow. śremski, stan. 6; 51 - Międzychód, stan. 1; 52 - Mosina, pow. poznański, stan. 3, 10, 11; 53 - Mściszewo, pow. poznański, stan. 2; 54 - Nądnia, pow. nowotomyski, stan. 1a, 3, 5, 6, 7; 55 - Niemierzyce, pow. grodziski, stan. 1 a: 56 Niesłabin, pow. śremski, stan. 4; 57 - Nietążkowo, pow. kościański; 58 - Niewierz, pow. szamotulski; 59 - Obomiki Wlkp., stan. 3; 60 - Orkowo, pow. śremski, stan. 1, 2; 61 - Owcze Głowy, pow. obornicki, stan. 4 oraz nieoznaczone; 62 - Pierwoszewo, pow. szamotulski; 63 - Policko, pow. międzyrzecki, woj. lubuskie, stan. Ic; 64 - Potrzanowo, pow. wagrowiecki, stan. 5; 65 - Poznań-Dębjec, stan. E; 66 - Poznań-Dolina Świętojańska; 67 - Poznań-Golęcin, stan. V; 68 - Poznań-Komandoria, ul. Grodzieńska, stan. 1; 69 - Poznań-Naramowice; 70 - Poznań-Szelag; 71 - Poznań-Szelag: 72 - Poznań, ul. Wolyńska 19; 73 - Poznań-okolice; 74 - Pożarowo, pow. szamotulski; 75 - Promnice, pow. poznański, stan. 3 oraz nieoznaczone: 76 Prosna, pow. chodzieski, stan. 1; 77 - Przemęt, pow. wolsztyński; 78 - Przysieka Polska, pow. kościański, stan. 11, 13 ; 79 Puszcza, pow. międzychodzki, stan. 2; 80 - Puszczykowo-Niwka, pow. poznański, stan. 2, 4; 81 - Racot, pow. kościański, stan. 6; 82 - Rogaczewo Wielkie, pow. kościański, stan. 13; 83 - Rogalinek, pow. poznański, stan. 17; 84 - Rogierówko, pow. poznański, stan. 2; 85 - Rożnowo, pow. obomicki, stan. 8, 9; 86 - Rudki, pow. obomicki, stan. 1; 87 - Rybojady, pow. międzyrzecki, woj. lubuskie, stan. 1: 88 - Separowo, pow. grodziski, stan. 1, 12; 89 - Sepienko, pow. kościański, stan. 7; 90 Slopanowo, pow. szamotulski, stan. 1; 91 - Sokolowice, pow. wolsztyński; 92 - Sowinki, pow. poznański, stan. 11; 93 - Stare Osowo, pow. obornicki, stan. 2; 94 - Strzyżewo, pow. nowotomyski, stan. 1, 3; 95 - Sulechów, pow. zielonogórski, woj. lubuskie; 96 - Śmiłowo, pow. szamotulski, stan. 2: 97 - Terespotockie, pow. nowotomyski, stan. 1; 98 - Uchorowo, pow. obomicki, stan. 9; 99 - Uścikowiec, pow. obornicki, stan. 2; 100 - Wartosław, pow. szamotulski; 101 - Widziszewo, pow. kościański, stan. 13, 15; 102 - Wielkie, pow. poznański, stan. 3;103 - Wiórek, pow. poznański, stan. 9, 12; 104 - Witoldzin, pow. szamotulski, stan. 1; 105 - Wróblewo, pow. szamotulski; 106 - Zaborowo, pow. wolsztyński.

U w a g i: ") KT - elementy uznane za właściwe dla kultury trzcinieckiej, szczególnie ceramika zdobiona dookolna plastyczną list wą oraz z pogrubionymi, facetowanymi wylewami.

Jeżeli nie zaznaczono inaczej, to miejscowości znajdują się w obrębie województwa wielkopolskiego.

${ }^{29}$ Numery podane w nawiasach odpowiadają numeracji stanowisk na rycinie 1.
${ }^{30}$ Gedl 1983, s. 42-45, Taf. 5: 120. 
Sytuacja kulturowa i osadnicza w dorzeczu środkowej Warty w początkach starszego okresu epoki brązu nie jest zupełnie jasna. Z pewnością nie można mówić tutaj o początkach stabilnego osadnictwa mogiłowego czy choćby nawet o bardziej intensywnych wpływach ze strefy zwartego zasięgu kultury przedłużyckiej. Wydaje się zatem, że obszary te były nadal zasiedlone przez późne ugrupowania kultury unietyckiej, ewentualnie tzw. kultury grobsko-śmiardowskiej, przekształcone u schyłku wczesnego okresu epoki brązu $\left(\mathrm{BA}_{2} / \mathrm{BB}_{1}\right)$ wskutek zakarpackich oddziaływań wieterzowskich.

$\mathrm{W}$ fazie klasycznej kultury przedłużyckiej, przypadającej na $\mathrm{BB}_{2}-\mathrm{BC}_{1}$ (środkowa i początki schyłkowej części II EB), obserwujemy już dość wyraźny napływ elementów mogiłowych w międzyrzecze Warty i Obry. Zapewne wtedy pojawiają się pierwsze nekropolie z grobami kurhanowymi, są one jednak dotychczas niezwykle słabo rozpoznane. Obecnie dysponujemy lakonicznymi informacjami o zaledwie 3 cmentarzyskach (Buków - nr 11, Dąbrowa - nr 16, Lipki Małe - nr 42), na których dokonano przypadkowych eksploracji szkieletowych pochówków, prawdopodobnie przykrytych nasypami kurhanowymi. Ocalały stamtąd tylko pojedyncze szpile brązowe, będące podstawą klasyfikacji chronologicznej. Niewątpliwie typowym wyznacznikiem fazy klasycznej jest pozyskana w jednym $z$ kurhanów w Bukowie szpila $z$ wrzecionowatą główką (odmiany Księże Wielkie), zdobiona bardzo charakterystycznym dla tego okresu motywem wielobocznej gwiazdy wpisanej w koła współśrodkowe ${ }^{31}$. Egzemplarze zarejestrowane na dwóch pozostałych cmentarzyskach reprezentują formy właściwe raczej dla młodszej części omawianej fazy bądź dla początków fazy schyłkowej. Za ich wcześniejszym datowaniem przemawia właśnie obecność motywu gwiazdy w ornamentach pokrywających główki. Tak więc wątek wirującej gwiazdy zdobi szpilę z wątorowatą główką (odmiany Krzydlina Mała), pochodzacą $z$ kurhanu w Dąbrowie ${ }^{32}$. Z kolei na szpili uchatej typu A z Lipek Małych, nawiązującej formą do datowanej już na pierwszą połowę III EB (BD) odmiany Trzęsów, znajduje się ornament zwielokrotnionej, wieloramiennej gwiazdy, pozwalający umieszczać ten egzemplarz jeszcze w ramach fazy klasycznej ${ }^{33}$.

$\mathrm{Z}$ fazą klasyczną należy ponadto wiązać naramienniki z tarczkami spiralnymi typu Miłosław (odmiana Miłosław i Trzebnica), które znamy ze skarbu z Lutomka ( $\mathrm{nr}$ 46) oraz z przypadkowego znaleziska w Owczych Głowach (nr 61). Nie jest to jednak pewne, gdyż okazy tego typu są formą stosunkowo długotrwała, najpóźniejsze zaś egzemplarze mogą pochodzić nawet $z$ pierwszej połowy III EB (BD) ${ }^{34}$. Spośród pozostałych ozdób obręczowych, na które składają się wyłącznie znaleziska bezkontekstowe, do fazy klasycznej dość pewnie można zaliczyć starszą odmianę otwartych bransolet o zgrubiałych i odgiętych końcach (Pierwoszewo - nr 62; Stare

\footnotetext{
${ }^{31}$ Gedl 1983, s. 60, Taf. 15: 210.

${ }^{32}$ Gedl 1983, s. 54, Taf. 10: 175.

${ }^{33}$ Gedl 1983, s. 77, Taf. 23: 312.

${ }^{34}$ Blajer 1984, s. $19,22,28$, Taf. 3: 11, 12; 8: 28
} 
Osowo - nr 93) oraz o zwężających się końcach (Lubiatów - nr 43), pokrytych charakterystycznym ornamentem tzw. wilczych zębów ${ }^{35}$. Bardzo nieliczne są natomiast znaleziska narzędzi i broni. Są to: siekierka z brzegami typu Wałowice (Promnice $\mathrm{nr} 75$ ), datowana szeroko pomiędzy II i III $\mathrm{EB}^{36}$, oraz 2 sztylety z półkolistą (Glinienko - nr 20) i trapezowatą (Oborniki - nr 59) nasadą do rękojeści, znalezione bezzespołowo ${ }^{37}$.

W fazie klasycznej, a więc od połowy II EB, następuje dość wyraźna ekspansja terytorialna kultury mogiłowej na tereny Wielkopolski. Obejmuje ona jednak przede wszystkim południowa strefę tego regionu, nie przekraczając $w$ zasadzie górnego i środkowego biegu Obry. Tam też, jak się wydaje, powstają bardziej stabilne formy osadnictwa, uchwytne archeologicznie przede wszystkim w postaci cmentarzysk (Kleszczewo, pow. Leszno; Kunowo, pow. Gostyń; Pudliszki, pow. Gostyń, stan. 3; Smoszew, pow. Krotoszyn). W świetle obecnej bazy źródłowej recepcja mogiłowych wzorców kulturowych fazy klasycznej przedstawia się w zachodniej Wielkopolsce nader skromnie. Przeważają tutaj pojedyncze znaleziska wyrobów brązowych, brak natomiast osad i cmentarzysk, które bezspornie można by uważać za ewidentne ślady stałego osadnictwa ludności kultury przedłużyckiej. Wzmiankowane powyżej nekropolie w Bukowie, Dąbrowie czy Lipkach Małych leżą na obrzeżach badanego obszaru (ryc. 1). Zapewne spora część stanowisk „ceramicznych”, trudnych do dokładniejszego określenia chronologicznego, pochodzi właśnie z fazy klasycznej, ale nie sposób tego obecnie dowieść. Mapa pewnie datowanych znalezisk z tego okresu wyraźnie pokazuje, że zwłaszcza międzyrzecze Warty i Obry, a więc obszar Pojezierza Poznańskiego, zaznacza się jako swoista biała plama. Niewykluczone, jak sugeruje to E. Kłosińska ${ }^{38}$, że nadal rozwijały się tutaj społeczności związane z nurtem późnej kultury unietyckiej, recypujące tylko oddziaływania mogiłowe ze Śląska lub z południowej Wielkopolski. Warto przy tym odnotować, że bardzo aktywny dotąd mikroregion kościański, z osadą w Bruszczewie, stan. 5, także nie wykazuje teraz jednoznacznych śladów zmiany kulturowej.

Zdecydowanie najliczniejszym zbiorem artefaktów związanych z kulturą przedłużycką dysponujemy dla fazy młodszej (schyłkowej), datowanej na $\mathrm{BC}_{2}-\mathrm{BD}$. Niestety, podobnie jak w odniesieniu do fazy poprzedniej, są to przeważnie pojedyncze znaleziska bezkontekstowe, względnie skarby o dość szerokich ramach chronologicznych. Wśród ozdób typowym wyznacznikiem są teraz długie szpile z tulejkowata główka, forma bardzo charakterystyczna dla kultury przedłużyckiej, nie występująca w zasadzie poza jej zasięgiem; w zachodniej Wielkopolsce stwierdzono dotychczas tylko 3 egzemplarze takich szpil ${ }^{39}$ : odmiany Zbrojewsko-Janu-

\footnotetext{
${ }^{35}$ Gedl 1975a, s. 36, 37, tabl. XIX: 16; Kłosińska 1997, tabl. LXI: 1, LXII: 11.

${ }^{36}$ Szpunar 1987, s. 65, 66, Taf. 21: 377.

${ }^{37}$ Gedl 1980a, s. 47, 57, Taf. 13: 94.

${ }^{38}$ Kłosińska 1997, s. 138, 139.

${ }^{39}$ Gedl 1983, s. 96-99, Taf. 28: 446; 29: 448; 32: 471.
} 
szewo (nr 25) i Kowalewko (nr 37) oraz odmiany Kujawki-Wróblewo (nr 105). Szpile z tulejkowatą główką stanowiły przeważnie wyposażenie grobów szkieletowych, okaz z Januszewa odkryto zaś najprawdopodobniej w grobie ciałopalnym. Dla fazy schyłkowej właściwe są ponadto: szpila $\mathrm{z}$ wątorowata główką odmiany Jeziora (Garbatka - nr 19), egzemplarz z główką w postaci spiralnej tarczki (Januszewo - nr 25) oraz szpila typu Buków (nr 11) z tejże miejscowości ${ }^{40}$. Zapewne na sam koniec owej fazy należy datować późne odmiany szpil uchatych typu A, odmiany Trzęsów (Buków - nr 11; Poznań-Szeląg - nr 71) ${ }^{4}$. Okazy takie współwystępują jeszcze z ceramiką guzowa w zespołach wczesnołużyckich z pierwszej połowy III EB (BD) (ryc. 4A). Równie późną pozycją chronologiczną legitymują się szpile typu Deinsdorf (Babimost - nr 1; Binino - nr 7; Przemęt - nr 77), forma szeroko rozpowszechniona na terenie Europy Środkowej na przełomie Il i III EB (BC/BD-BD); na ziemiach polskich występująca zarówno w zespołach późnomogiłowych, jak i jeszcze we wczesnołużyckich. Identyfikacja kulturowa znalezisk bezzespołowych, do których należą wszystkie okazy zachodniowielkopolskie, jest bardzo trudna, a dotychczasowe propozycje rozróżniania egzemplarzy schyłkowomogiłowych od wczesnołużyckich są mocno dyskusyjne ${ }^{42}$.

Ze schyłkową fazą kultury przedłużyckiej w zachodniej Wielkopolsce można wiązać większość naramienników z tarczkami spiralnymi, wchodzących w skład bądź stanowiących jedyny asortyment skarbów z Niewierza (nr 58), Witoldzina (nr 104) i Kowalewka (nr 37). Okazy z Niewierza i Witoldzina należą do typu Czernice (odmiany Czernice i Szczecin), występującego przede wszystkim na Pomorzu Zachodnim i datowanego dość szeroko - od $\mathrm{BB}_{2}$ do $\mathrm{HaA}_{1}{ }^{43}$. O ile jednak depozyt z Niewierza na podstawie kontekstu można odnosić do schyłkowej fazy kultury przedłużyckiej, o tyle dla pary naramienników z Witoldzina trudno jednoznacznie ustalić, czy pochodzą one ze schyłku II EB, czy też dopiero z początków III EB (BD) ${ }^{44}$. Szerokie ramy chronologiczne $\left(\mathrm{BB}_{2}-\mathrm{HaA}_{2}\right)$ cechują również użytkowanie naramienników typu Miechowice, do których zalicza się egzemplarze odkryte w bliskim sąsiedztwie rozległej nekropolii „łużyckiej” w Kowalewku. Także w tym przypadku skarb ów mógł zostać zdeponowany dopiero w pierwszej połowie III EB (BD), gdyż ramowa chronologia tej odmiany zawiera się pomiędzy $\mathrm{BC}$ a $\mathrm{BD}^{45}$. Pozostałe formy ozdób obręczowych reprezentują głównie młodsze warianty otwartych bransolet, zdobionych naprzemiennie polami poziomych i pionowych kresek, którym towarzyszą ukośnie zakreskowane trójkąty i linie zygzakowate. Są to okazy o zgrubialych

\footnotetext{
4) Gedl 1983, s. 58, 101, 104, Taf. 13: 198; 33: 481; 34: 508 .

${ }^{41}$ Gedl 1983, s. 78, 79, Taf. 23: 315; 24: 332.

${ }^{42}$ Essen 1985, s. 22 n., Taf. 5: 82, 84.

${ }^{43}$ Blajer 1984, s. 53, 56-59. Taf. 48: 150, 151; 54: 173, 174.

${ }^{44}$ Ostatnio W. Blajer (1999, s. 129, 130) sugeruje nawet, aby naramienniki z Witoldzina datować dopiero na $\mathrm{HaA}_{1}-\mathrm{HaA}_{2}$.

${ }^{45}$ Blajer 1999, s. 30 n., Taf. 20: 65, 66.
} 
i odgiętych końcach (Będlewo - nr 4) oraz egzemplarze o zwężających się końcach (Kowalewko - nr 37; Śmiłowo - nr 96) ${ }^{46}$. Bransolety z Będlewa współwystępowały z sierpem o lekko faliście wygiętym tylcu, nie spotykanym po pierwszej połowie III $\mathrm{EB}^{47}$. Natomiast dla dwóch pozostałych bransolet bliską analogię stanowią egzemplarze z kujawskiego grobu w Bożejewicach, pow. Mogilno, stan. 8, którym towarzyszyła szpila uchata typu C, odmiany Jelenin, datująca ów zespół na BC/BD ${ }^{48}$.

Większość narzędzi przypisywanych schyłkowej fazie kultury przedłużyckiej występuje także w zespołach, które można łączyć już z początkami kultury łużyckiej. Dotyczy to przede wszystkim siekierek, charakteryzujących się stosunkowo długim okresem użytkowania. Zwykle są one też w literaturze przedmiotu datowane na okres pomiędzy schyłkiem II EB a pierwszą połową III EB (BC-BD). Pośród okazów zachodniowielkopolskich przeważają znaleziska bezzespołowe, należące do dwóch zasadniczych grup typologicznych: siekierek z brzegami (typ Kłodzisko, odmiana A: Karśnice - nr 29, Kłodzisko - nr 31 oraz typ Czubin: okolice Poznania - nr 73) ${ }^{49}$ i z piętka. Śladem oddziaływań zakarpackich pod koniec starszego okresu epoki brązu (BC/BD) są dwa czekany: o podwójnym ostrzu (Sulechów - nr 95) i z tarczowatym obuchem (okolice Poznania). Niewątpliwie obydwa okazy można traktować jako ,importy” ze Słowacji lub Węgier i datować na przełom BC i BD ${ }^{50}$. Ponadto z militariów na baczniejszą uwagę zasługuje fragment grotu oszczepu typu Kirke Såby ze skarbu z Niewierza, o wyraźnie nordyjskiej proweniencji ${ }^{51}$.

Faza schyłkowa jest w zachodniej Wielkopolsce etapem najbardziej intensywnych oddziaływań/rozwoju (?) kultury mogiłowej. Zanika wówczas przodująca dotąd $w$ recepcji południowych (głównie śląskich) wzorców kulturowych rola skupiska kościańskiego, czyli regionu śmigielsko-krzywińskiego w ujęciu E. Kłosińskiej $^{52}$. Obok pojedynczych wytworów brązowych pojawiają się skarby zawierające głównie naramienniki z tarczkami spiralnymi. Na podkreślenie zasługuje trudność w przeprowadzaniu jednoznacznej klasyfikacji kulturowej (schyłkowomogiłowe - wczesnolużyckie) wielu bezkontekstowych znalezisk pochodzących $\mathrm{z}$ przełomu $\mathrm{BC}$ i $\mathrm{BD}$. W dużym stopniu ów problem dotyczy również skarbów brązowych, zawierających nierzadko wyroby datowane szeroko, pomiędzy $\mathrm{BB}_{2}$ a $\mathrm{BD}$, czy nawet $\mathrm{HaA}_{1}$ (np. Radzim-Maniewo, Międzyrzecz). Nadal też obraz oblicza kulturowego zachodniej Wielkopolski w starszym okresie epoki brązu nie rysuje się zbyt jasno, co w dużej mierze spowodowane jest ograniczoną wartością poznawczą materiału źródłowego, na który składają się w większości bezkontek-

\footnotetext{
${ }^{46}$ Gedl 1975a, s. 36, 37, tabl. XX: 1, XXXI: 8.

${ }^{47}$ Gedl 1995, s. 42.

${ }^{48}$ Coftu-Broniewska, Kosko 1982, s. 131, ryc. 55: 5, 7.

${ }^{49}$ Szpunar 1987, s. 59, 67, Taf. 17: 319;18: 230; 22: 397.

${ }^{50}$ Ged! 1975a, s. 56, tabl. V: 5.

${ }^{51}$ Fogel 1979, s. 89, 90; Bukowski 1998, s. 132, ryc. 45.

${ }^{52}$ Kłosińska 1997, s. 138, 139.
} 
stowe znaleziska wyrobów brązowych i słabo rozpoznane (powierzchniowo) stanowiska osadowe. Wyraźne są jednak różnice pomiędzy terenami położonymi na południe od równoleżnikowego biegu Obry a obszarami Pojezierza Poznańskiego. Strefa południowa lączy się ze skupiskiem stanowisk zlokalizowanych w międzyrzeczu górnej Obry, Orli i Baryczy, wchodzących w zasięg wyróżnionej przez B. Gedige $e^{53}$ grupy środkowośląsko-wielkopolskiej. Znajdują się tam cmentarzyska kurhanowe, i to począwszy od wczesnej fazy kultury przedłużyckiej ${ }^{54}$. Z Pojezierza Poznańskiego znamy zaś tylko kilka grobów, usytuowanych w dodatku na rubieżach analizowanego zasięgu. O chronologii wyróżnionych tutaj skupisk osadniczych $^{55}$ trudno powiedzieć coś pewnego, gdyż są one pozbawione dokładniejszych datowników, a ceramika reprezentuje cechy przypisywane zarówno kulturze mogiłowej, jak i trzcinieckiej (ryc. 1). Nie wykluczając istnienia kultury mogiłowej (przedłużyckiej) w zachodniej Wielkopolsce, co obecnie dość słabo dokumentują źródła nieruchome, należałoby się jednak zastanowić nad inną interpretacją sytuacji kulturowej na tym terenie. Wydaje się bowiem, że znaczną część międzyrzecza środkowej Warty i Obry jeszcze u schyłku starszego okresu epoki brązu mogły zamieszkiwać społeczności związane z nurtem późnej kultury unietyckiej, przekształconej w wyniku wpływów zakarpackich (wieterzowskich), dość opornie poddające się oddziaływaniom mogiłowym emitowanym ze Śląska i południowej Wielkopolski. Możliwość przeżywania się do $\mathrm{BB}_{2}$ takiego systemu kulturowego przyjmuje także E. Kłosińska ${ }^{56}$. Trudno natomiast zgodzić się $z$ tezą o nasileniu wpływów mogiłowych w czasach odpowiadających schyłkowej fazie kultury przedłużyckiej, jeśli zważy się, że spora część elementów datowanych na ten okres (głównie ze skarbów) pomimo afiliacji mogiłowych wykazuje jednak wyraźne powiązania $\mathrm{z}$ inwentarzami typowymi dla Pomorza Zachodniego (Niewierz, Witoldzin). Choć jest to pogląd ryzykowny, a jego falsyfikację wypada pozostawić przyszłym badaniom, wydaje się, iż w odniesieniu do sporej części zachodniej Wielkopolski można obecnie mówić - podobnie jak w przypadku Pomorza $^{57}$ - o fazie mogiłowej, nie zaś o istnieniu tutaj odrębnej jednostki kulturowej tego typu. Obszar zachodniej Wielkopolski w starszym okresie epoki brązu poddany był wielostronnym oddziaływaniom kulturowym (m.in. trzcinieckim), z których niewątpliwie wpływy mogiłowe były dominujące, uderzające jest jednak to, że nie zaznaczyły się one wyraźną obecnością stałych punktów osadniczych, w postaci osad i cmentarzysk. Poznanie ich ułatwiłoby z pewnością obserwację procesów kulturowych wiodących do pojawienia się tutaj pierwszych ugrupowań „,łużyckich”.

\footnotetext{
${ }^{53}$ Gediga 1978, s. 164.

${ }^{54}$ Gedl 1975a, mapa 4.

${ }^{55}$ Kłosińska 1992b, ryc. 3.

${ }^{56}$ Kłosińska 1997, s. 138, 139.

${ }^{57}$ Bukowski 1998, s. 124, 146, 147.
} 


\section{POCZĄTKI KULTURY LUŻYCKIEJ W ZACHODNIEJ WIELKOPOLSCE}

\section{ARCHEOLOGICZNE WYZNACZNIKI WCZESNEJ FAZY KULTURY ŁUŻYCKIEJ W ZACHODNIEJ WIELKOPOLSCE}

Rekonstrukcja procesu zmiany kulturowej należy w badaniach społeczności pradziejowych do bardzo intrygujących i zarazem trudnych przedsięwzięć, wymagających od archeologa nie tylko dobrej orientacji w materiale źródłowym, ale także odpowiedniego przygotowania teoretycznego, pozwalającego uniknąc konstruowania schematycznych modeli zachodzących procesów. W dotychczasowych, skrótowo opisanych wyżej próbach wyjaśnienia mechanizmów zaniku jednych kultur i pojawiania się w ich miejsce nowych jednostek, dominują dwa sposoby ujęcia tegoż zjawiska. W starszych opracowaniach przyjmowano zazwyczaj, że czynnikiem sprawczym wszelkich zmian kulturowych były migracje określonych grup ludzkich, nosicieli nowych wzorców kulturowych. Nieco później przestrzenną ekspansję nowych zachowań kulturowych zaczęto tłumaczyć jako „wędrówkę idei”, która nie wymagała fizycznych przemieszczeń określonych populacji. Tak między innymi u schyłku lat 60 . interpretowano fenomen rozprzestrzeniania się kultury pomorskiej. Ten drugi sposób wyjaśniania mechanizmów zmian kulturowych znacząco upodabnia się do modelu akulturacji, szczególnie intensywnie eksploatowanego w następnej dekadzie przez badaczy neolitu. Istota procesu akulturacji, koncepcji zrodzonej na gruncie antropologii kulturowej, była wówczas niejednokrotnie błędnie aplikowana w polskiej prahistoriografii, często przy użyciu możliwie najbardziej zawiłego słownictwa. Współcześnie pod pojęciem akulturacji, mimo wielu funkcjonujących definicji, rozumie się przede wszystkim proces przeobrażeń o wymiarze międzykulturowym, spowodowanych wymianą lub przepływem treści ${ }^{58}$.

Przystępując do omówienia początków kultury łużyckiej w zachodniej Wielkopolsce należy założyć, iż u genezy tego zjawiska leży właśnie proces akulturacji o wymiarze ponadregionalnym, obejmujący większość obszarów położonych w dorzeczu górnej i środkowej Odry. Jego rezultatem była pierwsza tak szeroka unifikacja kulturowa zachodniej części ziem polskich, obserwowalna zwłaszcza w tzw. fazie wczesnołużyckiej. Wydaje się, że przepływ nowych treści kulturowych następował w dwojaki sposób, a więc zarówno dzięki dyfuzji poszczególnych elementów, jak i poprzez ograniczona migrację określonych grup ludzkich. Poniżej przedstawiam próbę skonfrontowania oraz uszczegółowienia tych założeń $\mathrm{z}$ dostępnym obecnie materiałem źródłowym.

Kształtowanie się nowego oblicza kulturowego zachodniej Wielkopolski w początkach środkowego okresu epoki brązu wyznaczają ciałopalne zespoły grobowe, zawierające ceramikę guzową typu śląsko-wielkopolskiego, właściwą dla większości obszarów usytuowanych w dorzeczu środkowej Odry (ryc. 2). Najpewniej proces

${ }^{58}$ Posern-Zieliński 1993, s. 39 n. 
ten, datowany na $\mathrm{BD}$, a więc na początki III EB, nastapił równolegle w zachodniej Wielkopolsce i na sąsiedniej ziemi lubuskiej; obszary te łączy się zwykle w jedna grupę kultury lużyckiej, zwaną zachodniowielkopolską ${ }^{59}$ lub brandenburskolubuska ${ }^{60}$. W obu wspomnianych regionach brak dotychczas bardziej przekonujacych dowodów na istnienie najwcześniejszego horyzontu łużyckiego ze schyłku II EB (BC), z jakim mamy do czynienia na Dolnym Śląsku (zwłaszcza w jego środkowej części) i w południowej części Górnego Śląska. Pojawia się tutaj dopiero ceramika zdobiona rozwiniętym ornamentem guzowym, właściwym już dla całego III EB (BD-HaA $)$.

Wczesnołużycki styl guzowy w ceramice z zachodniej Wielkopolski, oprócz kontynuacji niektórych form wcześniejszych, wiąże się z szeregiem nowych morfotypów, właściwych wyłącznie dla nowo powstającej kultury łużyckiej. Charakterystyczne są przede wszystkim wazy z lejkowatą szyjką i wylewem kołnierzowato wychylonym na zewnątrz (tzw. kryza) (ryc. 3B: 6; 4D: 2; 6A: 3; 7A: 3, B: 2, 4), wazy z baniastym brzuścem i cylindryczną szyjką (ryc. 3B: 10; 4A: 2, B: 10, D: 7; 5C: 6,$8 ; 6 \mathrm{~B}: 12 ; 7 \mathrm{~A}: 1$ ), amfory $\mathrm{z}$ baniastym lub elipsowatym brzuścem i cylindryczną szyjką (ryc. 3A: 9, B: 4, 7-9; 4B: 3, 9, D: 8, 9; 7A: 6), dzbany i kubki z podobnie uksztaltowanym brzuścem lecz stożkowatą szyjką (ryc. 3A: 8, B: 5; 4B: 6, 7, D: 6; 5A: 1, 9, B: 1; 6A: 9, B: 13, C: 3; 7A: 4, B: 1), jajowate garnki z lejkowato wychyloną krawędzią wylewu (ryc. 4B: 5, 8, D: 4; 5A: 5, 6, 8, B: 2; 6A: 1, 3, 11, B: $6-8,10,11, \mathrm{C}: 1,2,4 ; 7 \mathrm{~A}: 5,7)$ oraz trójsegmentowe misy z lejkowatą szyjką i wystającym na zewnątrz wylewem (niekiedy facetowanym) (ryc. 3B: 3; 4B: 2, C: 1, D: 1; 5A: 7, B: 3; 6B: 4; 7A: 2, B: 3). Wśród nich niewątpliwie „spuścizną" $\mathrm{z}$ okresu mogiłowego są niektóre formy wspomnianych waz i mis ${ }^{61}$.

Znacznie mniej elementów z poprzedniego okresu spotykamy w ornamentyce. Dodatkowym utrudnieniem badań jest fakt, że ceramika kultury przedłużyckiej jest tutaj bardzo słabo rozpoznana. Najbardziej typowym wyznacznikiem początków kultury lużyckiej w ceramice zachodniowielkopolskiej jest ornament guzowy, którym dekorowano tylko wazy, amfory i dzbany. Najczęściej były to guzy silnie wypychane od wnętrza, przez co naczynia przybierały formę wieloboczną w rzucie poziomym (ryc. 3B: 9; 4D: 9). Uzupełnieniem guzów był przede wszystkim linearny ornament ryty, występujący również samodzielnie. Poza tym naczynia zdobiono innymi elementami plastycznymi, jak choćby szerokimi, ukośnymi kanelurami czy żeberkami umieszczanymi zwykle na największej wydętości brzuśca. W świetle typologicznej klasyfikacji ornamentu guzowego przeprowadzonej przez M. Kwapińskiego $^{62}$ znaleziska zachodniowielkopolskie stanowią część większego skupiska w dorzeczu środkowej Odry, określonego jako aglomeracja lubusko-wielkopolska. Sty-

\footnotetext{
${ }^{59}$ Kostrzewski 1955, s. 96 n., mapka 6, 7.

${ }^{60)}$ Gedl 1975b, s. 118, 119, mapa 1, 2.

${ }^{61}$ Kłosińska 1997, s. 42-44, ryc. 10, 11.

${ }^{62}$ Kwapiński 1985, s. 15, 16, mapa 3.
} 
A

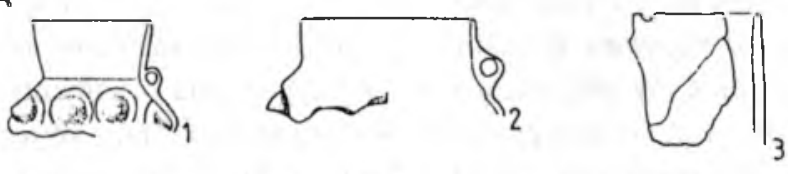

3
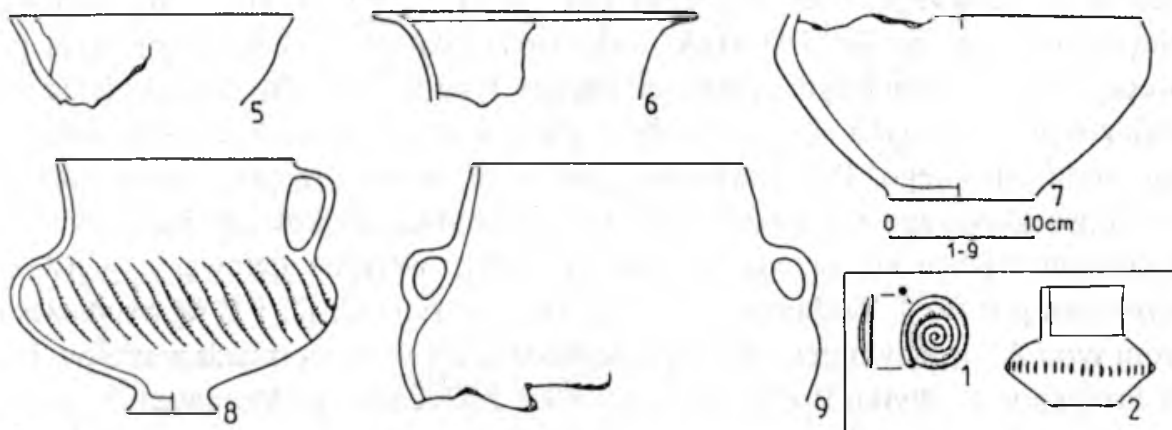

B
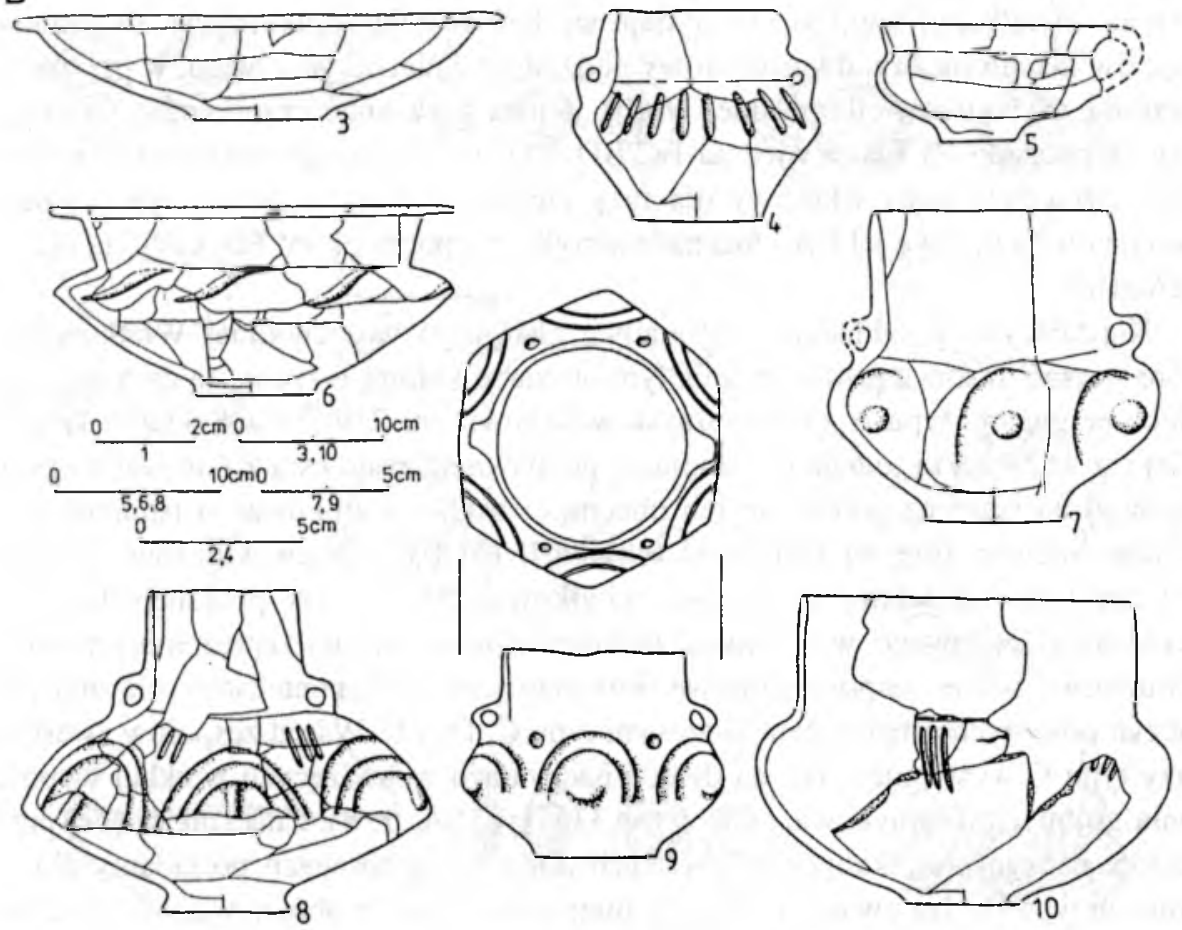

Ryc. 3. Zachodniowielkopolskie zespoły grobowe z wczesnołużycką ceramiką guzową

A - Plomykowo, stan. 1, grób 1, B - Święty Wojciech, stan. 10, obiekt (grób) 124.

A - wg U. Dymaczewskiej (1963), B - wg A. Krzyszowskiego (1998)

Fig. 3. Grave assemblages with early Lusatian culture knobbed pottery from western Wielkopolska

A - Plomykowo, site 1, grave 1; B - Święty Wojciech, site 10, fearure (grave) 124.

A - according to U. Dymaczewska (1963), B - according to A. Krzyszowski (1998) 
listyka zdobnictwa ceramiki lubusko-wielkopolskiej wykazuje szereg cech wspólnych, a także zbliżone trendy rozwojowe $z$ okazami tworzącymi dwa sąsiednie skupiska: dolnośląskie i dolnołużyckie. W pierwszej fazie występowania ornamentyki guzowej, datowanej na $\mathrm{BB}_{2}-\mathrm{BC}$ i nazwanej przez $\mathrm{M}$. Kwapińskiego ${ }^{63}$ fazą dywergencji stylu guzowego, dominuja guzy typu $A, D_{1}, C$ i E. Z kolei fazę młodsza, umieszczaną $w$ przedziale $\mathrm{BD}-\mathrm{HaA}_{1} \mathrm{i}$ określoną jako stadium unifikacji stylu guzowego, wyznaczają naczynia zdobione guzami typu $B_{2}, D_{2}$ i $D_{3}$. Jedynie ornament guzowy typu $\mathrm{B}_{1}$ spotyka się przez niemal cały okres występowania wczesnołużyckiego stylu guzowego. Przedstawionego powyżej dynamicznego modelu rozwoju zdobnictwa guzowego nie można jednak zaakceptować całkowicie bezkrytycznie. Dyskusyjne wydaje się przede wszystkim nazbyt wczesne datowanie pierwszej z wyróżnionych faz ${ }^{64}$. Zakładając bowiem, iż guzy typu C, $D_{1}$ i E są współczesne guzom typu $\mathrm{A}$, będącym przecież wyznacznikiem najwcześniejszych zespołów kultury łużyckiej ze schyłku II EB (BC) na Śląsku, Łużycach i na Morawach ${ }^{65}$, należałoby dokonać korekty datowania początków kultury łużyckiej w strefie lubuskozachodniowielkopolskiej, co nie wydaje się być w pełni uzasadnione. Przyjmując więc ów diachroniczny, dwustopniowy podział zdobnictwa guzowego, w przypadku ceramiki zachodniowielkopolskiej trzeba jednak przesunąc chronologię pierwszej fazy na początki III EB, a więc na $\mathrm{BC} / \mathrm{BD}-\mathrm{BD}$. W ten sposób ornament określony jako późniejszy, czyli właściwy dla fazy unifikacji stylu guzowego, przypadałby tutaj na drugą połowę III EB i nieznacznie tylko na początek IV EB, czyli na $\mathrm{HaA}_{1}-$ $\mathrm{HaA}_{1} / \mathrm{HaA}_{2}$.

Najstarszymi przykładami zdobnictwa guzowego w zachodniej Wielkopolsce, które wiązać można z powstającą na tym obszarze kulturą łużycką są dwa naczynia zdobione guzami typu A z cmentarzysk w Łęgowie ( $\mathrm{nr} 229)^{66} \mathrm{i}$ w Szklarce Trzcielskiej (nr 467). Są to jednak egzemplarze pozbawione kontekstu źródłowego i przynajmniej na razie na podstawie ich obecności trudno wyrokować o istnieniu tutaj najwcześniejszej fazy tej kultury ze schyłku II EB (BC). Niewykluczone, iż moga one być pozostałościami osadnictwa schyłkowej fazy kultury przedłużyckiej. Początki stylu guzowego $w$ ceramice zachodniowielkopolskiej reprezentują ponadto stosunkowo liczne zespoły grobowe oraz cały szereg bezkontekstowych znalezisk naczyń pokrytych ornamentem guzowym typu $\mathrm{C}, \mathrm{D}_{1}$ i E. Wśród zespołów zwartych guzy typu C występują tylko na dwóch naczyniach wchodzących w skład wyposażenia grobu 1 z Płomykowa, stan. 1 (nr 336; ryc. 3A: 1, 2). Znacznie więcej przykładów naczyń pozyskanych ze zwartych obiektów grobowych posiadamy dla ornamentu typu $D_{1}$. Na uwagę zasługują tutaj inwentarze grobów: 2 (ze szpilą uchatą

\footnotetext{
${ }^{63}$ Kwapiński 1985, s. 36, 37.

${ }^{64}$ Wskazywał na to już A. Marcinkian (1986, s. 106, przyp. 14).

${ }^{65}$ M.in. Gedl 1974a, s. 21-31, Abb. 2, 7, 8; 1979, Abb. 5, Taf. III: 4, 9, IV: 9, 17, 18; 1980b, s. 85,

${ }^{66}$ Numery w nawiasach odpowiadają numeracji stanowisk na rycinie 2.
} 86 , ryc. 2. 


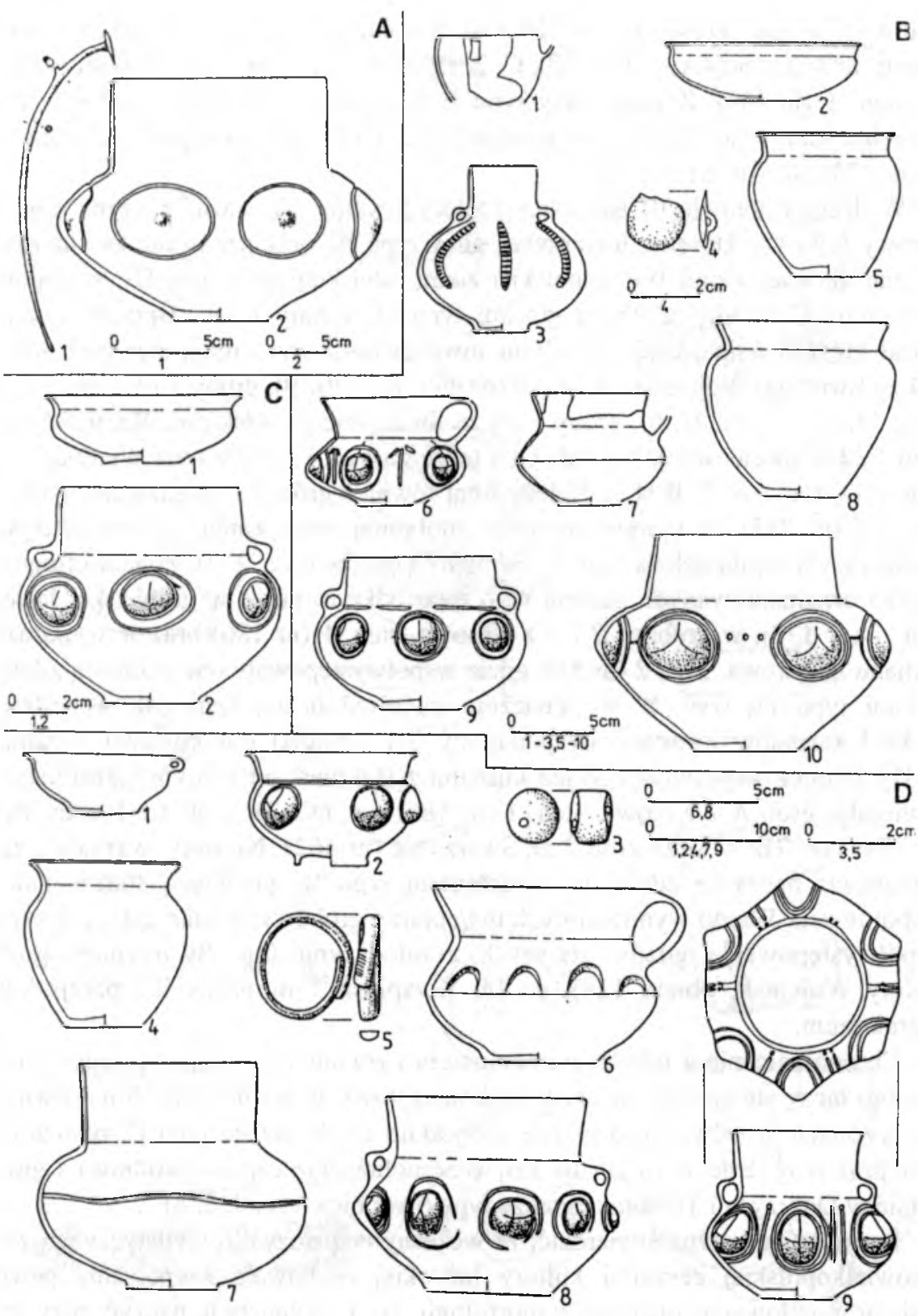

Ryc. 4. Zachodniowielkopolskie zespoły grobowe z wczesnolużycką ceramiką guzową

A - Swarzynice, grób 2; B - Swarzynice, grób 5; C - Swarzynice, grób 10; D-Swarzynice, grób 9. A - wg M. Kwapińskiego (1974b) , B-D - wg A. Marcinkiana (1975)

Fig. 4. Grave assemblages with early Lusatian culture knobbed pottery from western Wielkopolska A - Swarzynice, grave 2; B - Swarzynice, grave 5; C - Swarzynice, grave 10; D - Swarzynice, grave 9. A - according to M. Kwapinski (1974b), B-D - according to A. Marcinkian (1975) 
typu A, odmiana Trzęsów), 5, 9 i 10 z wczesnolużyckiego cmentarzyska w Swarzynicach (nr 462; ryc. 4A: 2, B: 9, 10, C: 2, D: 2, 8) oraz grób 1 z nekropolii w Jasieńcu, stan. 1 (nr 138). Z kolei guzy typu E odnotowano w dwóch grobach (1 i 2) z Poręby, stan. 1 (nr 346) oraz w jednym (obiekt 124) ze Świętego Wojciecha, stan. 10 (nr 479; ryc. 3B: 8).

W drugiej połowie III EB $\left(\mathrm{HaA}_{1}\right)$ zdecydowanie przeważać zaczyna ornament guzowy typu $\mathrm{D}_{2}$, któremu towarzyszą guzy typu $\mathrm{B}_{2}$ oraz uznawane za charakterystyczne dla zachodniej Wielkopolski i ziemi lubuskiej guzy typu $\mathrm{D}_{3}$, z pionowym żeberkiem. Ceramikę zdobioną guzami typu $\mathrm{D}_{2}$ znamy z 18 zespołów zwartych, wśród których najbardziej okazałymi inwentarzami wyróżniają się: grób (obiekt) 124 ze Świętego Wojciecha, stan. 10 (nr 479, ryc. 3B: 9), groby 1 i 9 z Borka, stan. 1 (nr 33, ryc. 5A: 9, C: 6), groby 1 i 9 ze Swarzynic (nr 462, ryc. 4D: 9, 7A: 3, 4), grób 2 z Bukowca (nr 50, ryc. 5B: 1), a także groby 1 i 2 ze Smolna Wielkiego, stan. 1 (nr 437, ryc. 6A: 5, B: 13). Należy tutaj również grób 3 z Międzyrzecza-Obrzyc, stan. 53 (nr 255), w którym ceramice zdobionej ornamentem guzowym typu $\mathrm{D}_{2}$ towarzyszyła szpila uchata typu C, odmiany Opatów (ryc. 9: 2). Ponadto fragmenty naczyń ornamentowanych guzami tego typu odkryto także $w$ grobie $4 \mathrm{z}$ Jasieńca, stan. 1 (nr 138), w grobach 2 i 3 z Kotowa, stan. 1 (nr 186) oraz w wyposażeniu kurhanu z Bukowa, stan. 2 ( $\mathrm{nr} 51$ ), gdzie współwystępowały one $\mathrm{z}$ amforą zdobioną guzami typu $\mathrm{D}_{3}$ (ryc. 8: 4). Znacznie mniejszą liczbą znalezisk wchodzących w skład zespołów zwartych dysponujemy dla ceramiki dekorowanej guzami typu $\mathrm{D}_{3}$. Oprócz wspomnianego już kurhanu z Bukowa, po jednym takim naczyniu zawierały: grób A z Kotowa, stan. 1 (nr 186; ryc. 6C: 3), grób 4 z Roska, stan. 2 (nr 399; ryc. 7B: 4) oraz grób 7 ze Swarzynic (nr 462). Niestety, wszystkie znane dotychczas naczynia zdobione ornamentem typu $\mathrm{B}_{2}$ pochodzą spoza znalezisk zespołowych. Wśród wymienionych inwentarzy grobowych zdarzają się przypadki współwystępowania guzów starszych z młodszymi (np. Swarzynice, grób 9, Święty Wojciech, obiekt 124), co M. Kwapiński ${ }^{67}$ tłumaczy ich przejściowym charakterem.

Chronologicznie z młodszym odcinkiem rozwoju wczesnołużyckiego stylu guzowego łączy się szereg znalezisk bezkontekstowych, pochodzących najpewniej ze zniszczonych grobów. Są to przede wszystkim szpile uchate typu C, odmiany Buków oraz popularne w całym III EB wczesnołużyckie szpile z kolbowatą główka, odmiany Dobrzyca i Trzebnik, a także typu Swobnica (ryc. 9: 3,4$)^{68}$.

Reasumując można stwierdzić, że wczesny etap rozwoju stylistycznego zachodniowielkopolskiej ceramiki kultury łużyckiej cechowało zachowanie pewnych tradycji mogiłowych, zarówno w morfologii, jak i zdobnictwie naczyń, przy jednoczesnym krystalizowaniu się nowych wzorców właściwych już dla nowo formujacej się „popielnicowej” kultury młodszej epoki brązu. Jego chronologię umieszcza się

\footnotetext{
${ }^{67}$ Kwapiński 1985, s. 37.

${ }^{68}$ Essen 1985, s. 13, 39, 44, 51.
} 
A
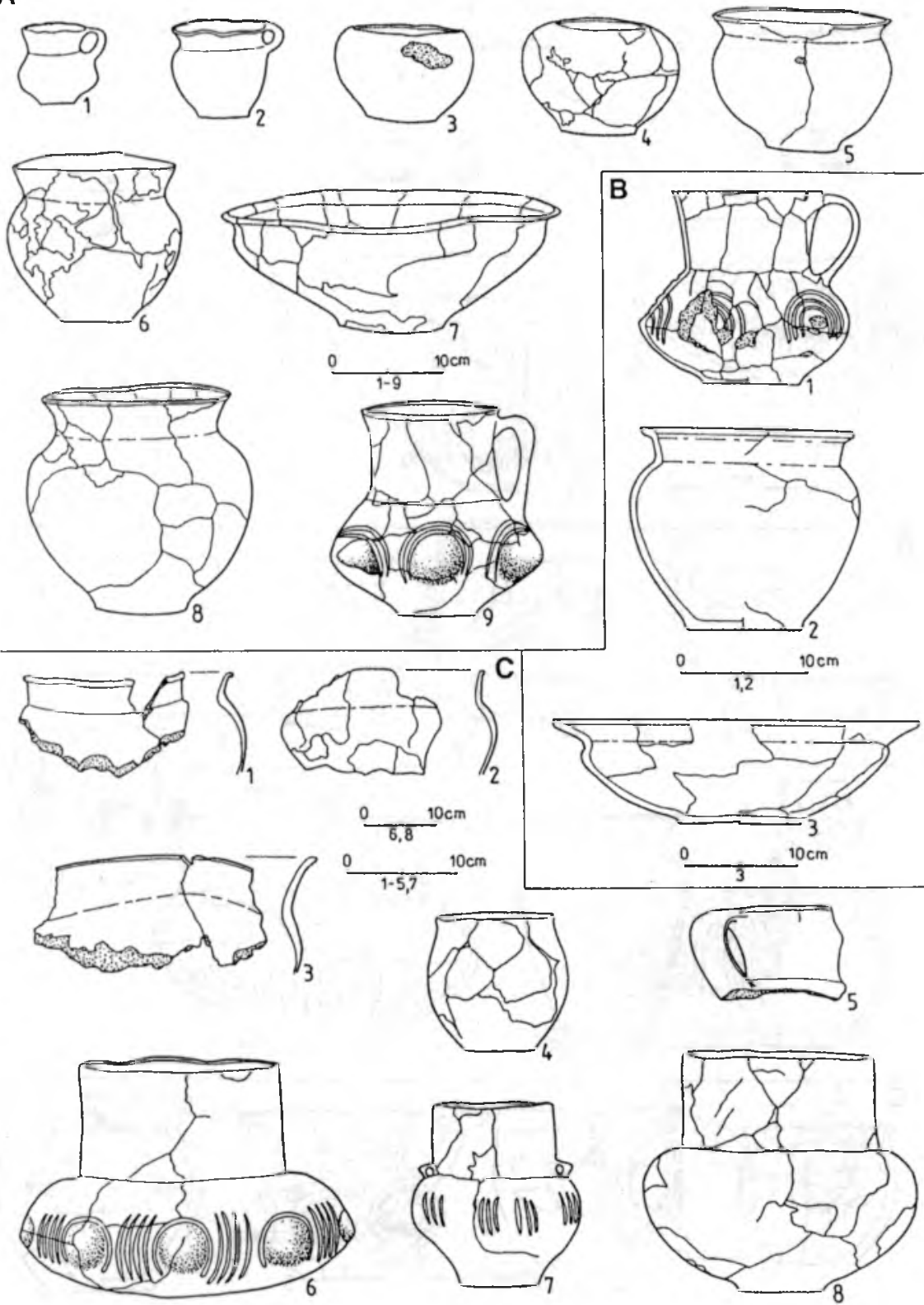

Ryc. 5. Zachodniowielkopolskie zespoły grobowe z wczesnołużycką ceramiką guzową A - Borek, stan. 1, grób 9; B - Bukowiec, grób 2; C - Borek, stan. 1. grób 1. A, C - wg S. Jasnosza (1953), B - wg S. Kurnatowskiego (1966)

Fig. 5. Grave assemblages with early Lusatian culture knobbed pottery from western Wielkopolska A - Borek, site 1, grave 9; B - Bukowiec, grave 2; C - Borek, site 1, grave 1 . A, C - according to S. Jasnosz (1953), B - according to S. Kurnatowski (1966) 

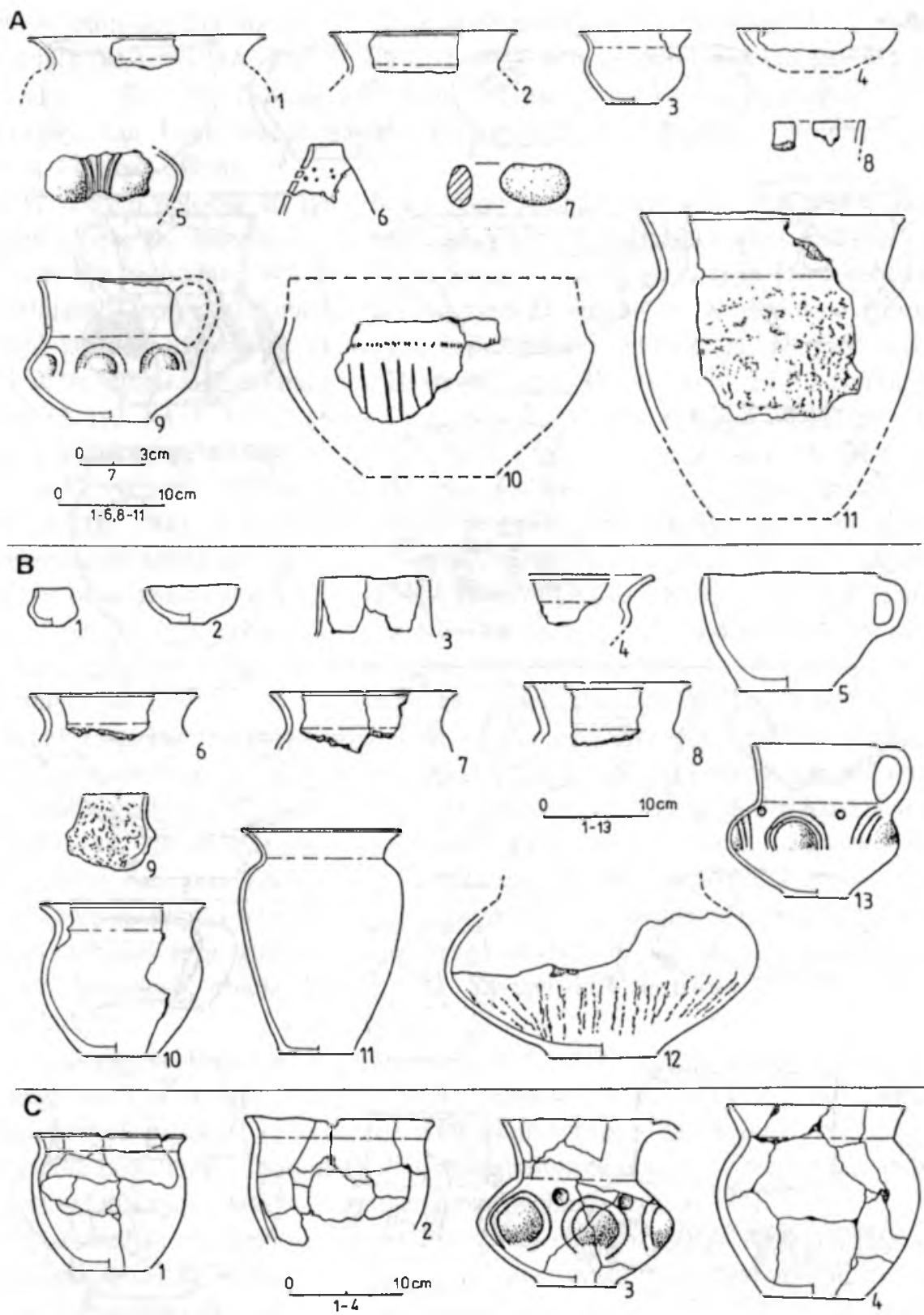

Ryc. 6. Zachodniowielkopolskie zespoły grobowe $\mathrm{z}$ wczesnolużycką ceramiką guzową A - Smolno Wielkie, stan. 1, grób 2; B - Smolno Wielkic, stan. 1, grób 1; C - Kotowo, stan. 1, grób A. A, B - wg J. Ostoja-Zagórskiego (1974), C - wg A. Lipińskiej (1961)

Fig. 6. Grave assemblages with early Lusatian culture knobbed pottery from western Wielkopolska A - Smolno Wielkie, site 1, grave 2: B -Smolno Wielkie, site 1, grave 1; C-Kotowo, site 1, grave A. A, B - according to J. Ostoja-Zagórski (1974), C - according to A. Lipińska (1961) 
A

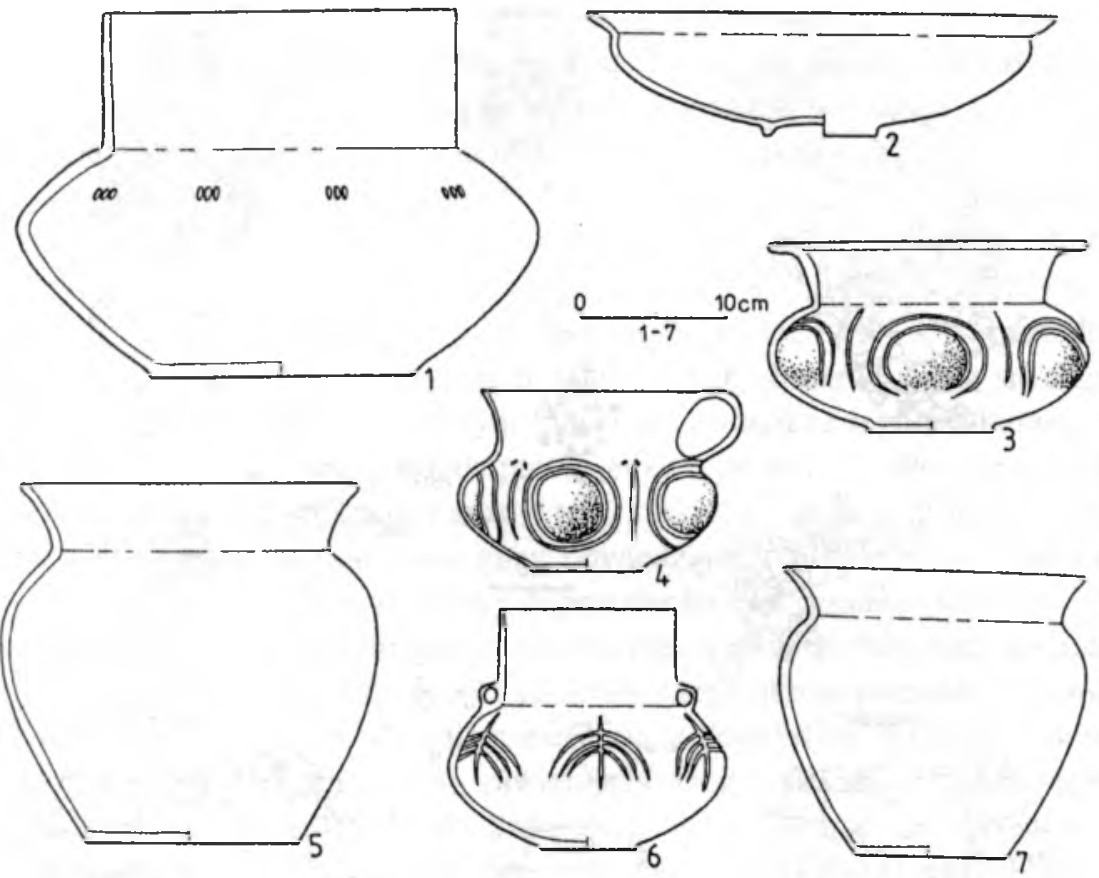

B
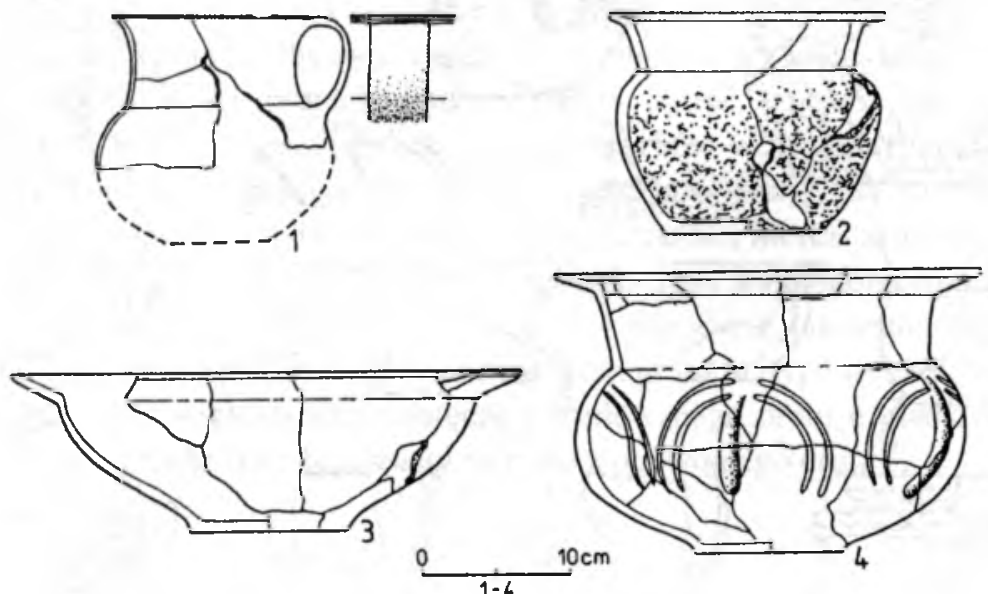

Ryc. 7. Zachodniowielkopolskie zespoły grobowe $\mathrm{z}$ wczesnołużycką ceramiką guzową A-Swarzynice, grób 1; B-Rosko, stan. 2, grób 4.

A - wg M. Kwapińskiego (1974b), B - wg S. Kurnatowskiego (1966)

Fig. 7. Grave assemblages with early Lusatian culture knobbed pottery from western Wielkopolska A - Swarzynice, grave 1; B - Rosko, site 2, grave 4.

A - according to M. Kwapiński (1974b), B - according to S. Kurnatowski (1966) 

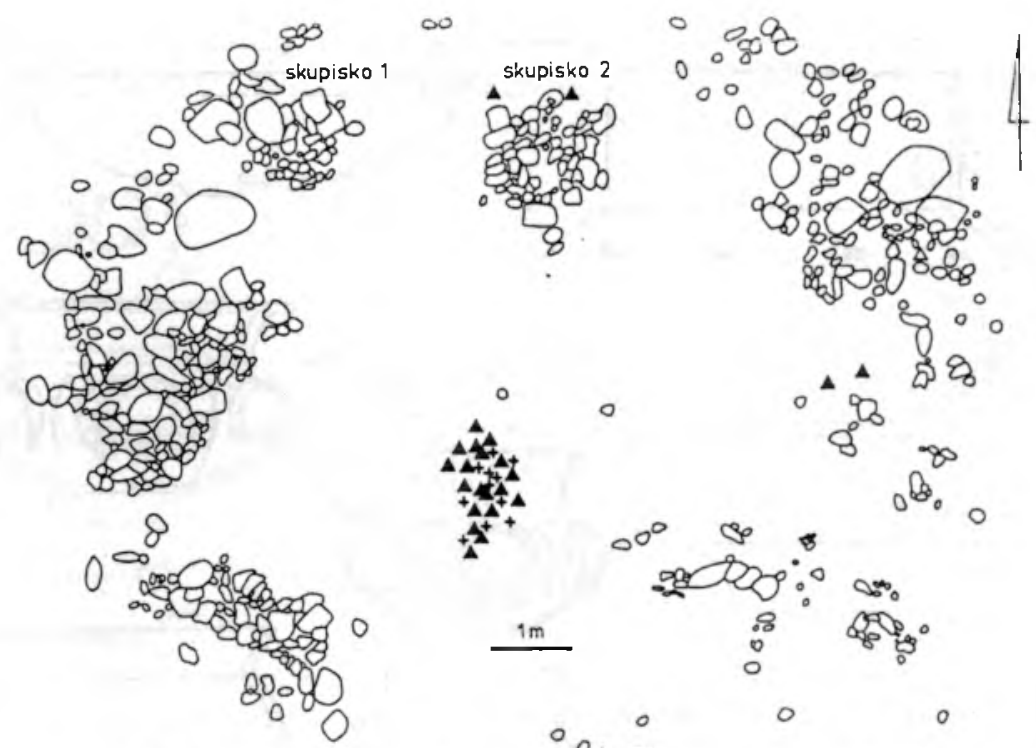

skupisko 1
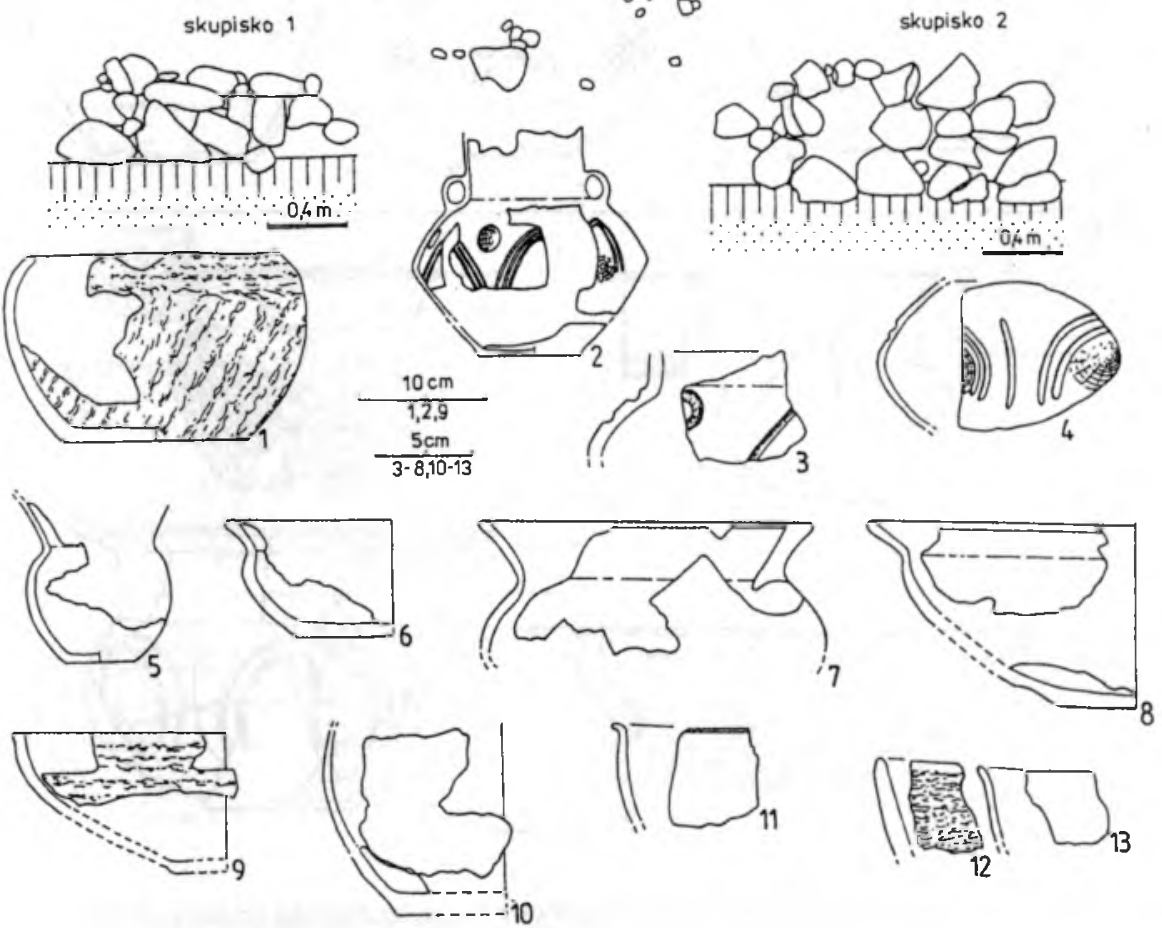

Ryc. 8. Rzut poziomy i wyposażenie grobu kurhanowego z Bukowa, stan. 2

wg M. Kwapińskiego (1974a)

Fig. 8. Plan and grave goods from the Buków barrow, site 2 according to M. Kwapiński (1974a) 
zwykle $w$ ramach III EB, a więc $w$ przedziale $B D-\mathrm{HaA}_{1}$. Na analizowanym obszarze nieliczne zespoły (np. Swarzynice, grób 2 - ryc. 4A) zdają się wskazywać na to, iż pojawienie się stylu guzowego można by wiązać już z początkami III EB, a więc z BD. Stylistyczna łączność garncarstwa zachodniowielkopolskiego z lubuskim i wschodniobrandenburskim, przy zachowaniu pewnych lokalnych odrębności zdaje się nie podlegać dyskusji. Niewątpliwie tutejsza wytwórczość była inspirowana przez śląską i sasko-łużycką ceramikę guzową. Jednak wbrew sugestiom M. Ge$\mathrm{dla}^{69}$, który wyłącznie oddziaływaniom ze strony grupy sasko-łużyckiej przypisuje znaczącą rolę $w$ powstaniu kultury łużyckiej na ziemi lubuskiej i w zachodniej Wielkopolsce, w zdobnictwie guzowym ceramiki z tych obszarów zdają się zaznaczać jednak silniejsze związki z Dolnym Śląskiem, zwłaszcza jego środkową częścią. Oto bowiem w zachodniej Wielkopolsce guzy typu B i C, nawiązujące tylko pośrednio do dużych, talerzowatych guzów typu saskiego ${ }^{70}$, reprezentowane są bardzo skromnie. Przeważają natomiast guzy obwiedzione podkowiastymi żłobkami typu $D_{1}$ i $D_{2}$, analogiczne do występujących powszechnie na ceramice śląskiej ${ }^{71}$.

Sporo trudności sprawia chronologiczna korelacja wczesnołużyckich zespołów grobowych z zachodniej Wielkopolski ze znanymi z tego okresu gromadnymi znaleziskami wyrobów brązowych. Za najwcześniejszy z depozytów brązowych należy uznać skarb z Międzyrzecza ( $\mathrm{nr}$ 253), zawierający obok 3 siekierek z prostą piętką typu wielkopolskiego (ryc. 10: 1, 3, 4), związana jeszcze ze starszym okresem epoki brązu siekierkę z brzegami typu Wałowice (ryc. 10: 2). Równie wczesne elementy znajdują się $w$ inwentarzu zespołu zakumulowanego z Radzimia-Maniewa, stan. 4 (nr 75), w tym zwłaszcza charakterystyczne dla BD miecze ze sztabą do rękojeści typu Annenheim i Traun ${ }^{72}$. Obydwa znaleziska, występujące właściwie na pograniczu okresu mogiłowego $\mathrm{i}$ popielnicowego, należy łączyć zapewne $\mathrm{z} 1$. połową III EB, a więc $\mathrm{z} \mathrm{BD}^{73}$. Pozostała, większa część skarbów wczesnołużyckich z zachodniej Wielkopolski datowana jest ramowo na $\mathrm{HaA}_{1}-\mathrm{HaA}_{2}$. Sa to: Wilenko (nr 102, ryc. 11), Marianowo, Drezdenko (nr 14), Szczaniec, Siercz, skarb II (nr 82) i Witkowice (nr 103). Oprócz siekierek z prosta piętką typu wielkopolskiego, siekierek ze środkowymi skrzydełkami (ryc. 11: 1,2) i sierpów z łukowato wygiętym tylcem, występują tutaj bransolety zdobione kanelurami (m.in. typu Droszków - ryc. 11: 10, 12-17), oraz wielozwojowe obręcze $\mathrm{z}$ tordowanego drutu o gładkich końcach. Pojawiają się także złote bransolety spiralne z podwójnego drutu ${ }^{74}$.

${ }^{69}$ Gedl 1975b, s. 118.
${ }^{70}$ Coblenz 1952, s. 66-77, Taf. 1-30, 36-61.
${ }^{71}$ M.in. Kleemann 1977, s. 59-72, Taf. 19, 11-17; Gediga 1967, s. 183, ryc. 3-6, 8; 1982, tabl. 1; Gedl 1977, s. 47, ryc. 5: 1, 4, 6; 1980b, s. 88, 90, ryc. 4; Kwapiński 1985, zestawienia 5-8.

${ }^{72}$ Kurnatowski 1966, s. 163-166, ryc. 50, tabl. IV: 4, 9, 11, V: 6; Riemer 1997.

${ }^{73}$ W. Blajer $(1990 \mathrm{~b}, \mathrm{~s} .14,20)$ zakłada dla tych zespołów nieco szersze ramy chronologiczne BC$\mathrm{HaA}_{2}$.

${ }^{74}$ Kurnatowski 1966, s. 178,179 , ryc. 71. 


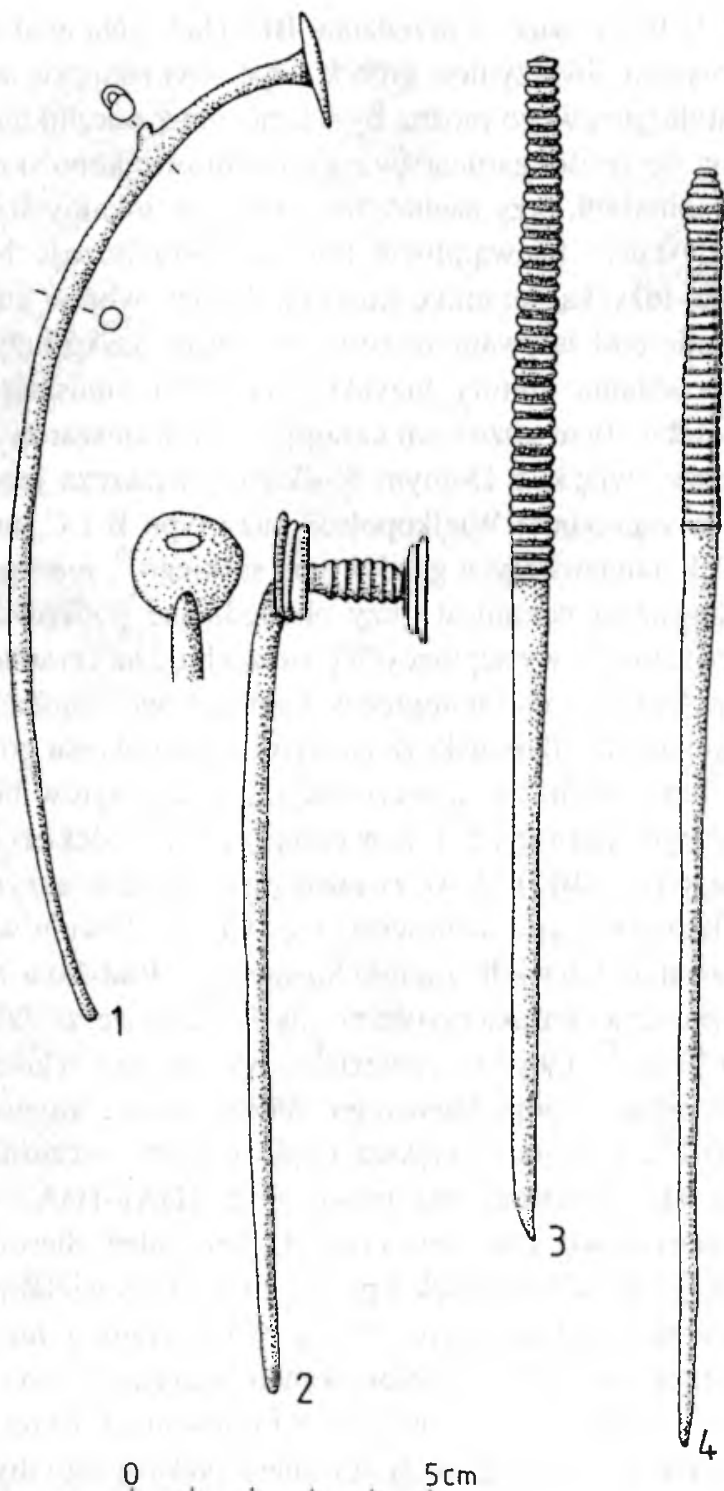

Ryc. 9. Zachodniowielkopolskie szpile uchate i z wrzecionowatą główką

Szpile uchate. Typ A, odmiana Trzęsów: 1 - Swarzynice, grób 2. Typ C, odmiana Opatów: 2 - Międzyrzecz-Obrzyce, stan. 53, grób 3. Szpile z wrzecionowatą główką. Szpila z wrzecionowatą, cylindryczną główką, odmiana Dobrzyca: 3 - Obra, stan. 1. Typ Swobnica: 4 - Oborniki Wlkp., stan. 3

I - wg M. Gedla (1983), 2-4 - wg R. Essen (1985), 5 - wg D. Durczewskiego i W. Śmigielskiego (1966)

Fig. 9. Bronze pins with an eyelet and bronze mould-headed pins from western Wielkopolska

Bronze disc-headed pins with an eyelet on a shrank. Type A, variant Trzęsów: 1 - Swarzynice, grave 2 . Bronze pins with a head flattened and curled into an eyelet. Type C, variant Opatów: 2 - Międzyrzecz-Obrzyce, site 53, grave 3. Bronze mould-headed pins, variant Dobrzyca: 3 - Obra, site 1. Type Swobnica: 4 - Oborniki Wlkp., site 3

1 - according to M. Gedl (1983), 2-4 - according to R. Essen (1985), 5 - according to D. Durczewski and W. Śmigielski (1966) 

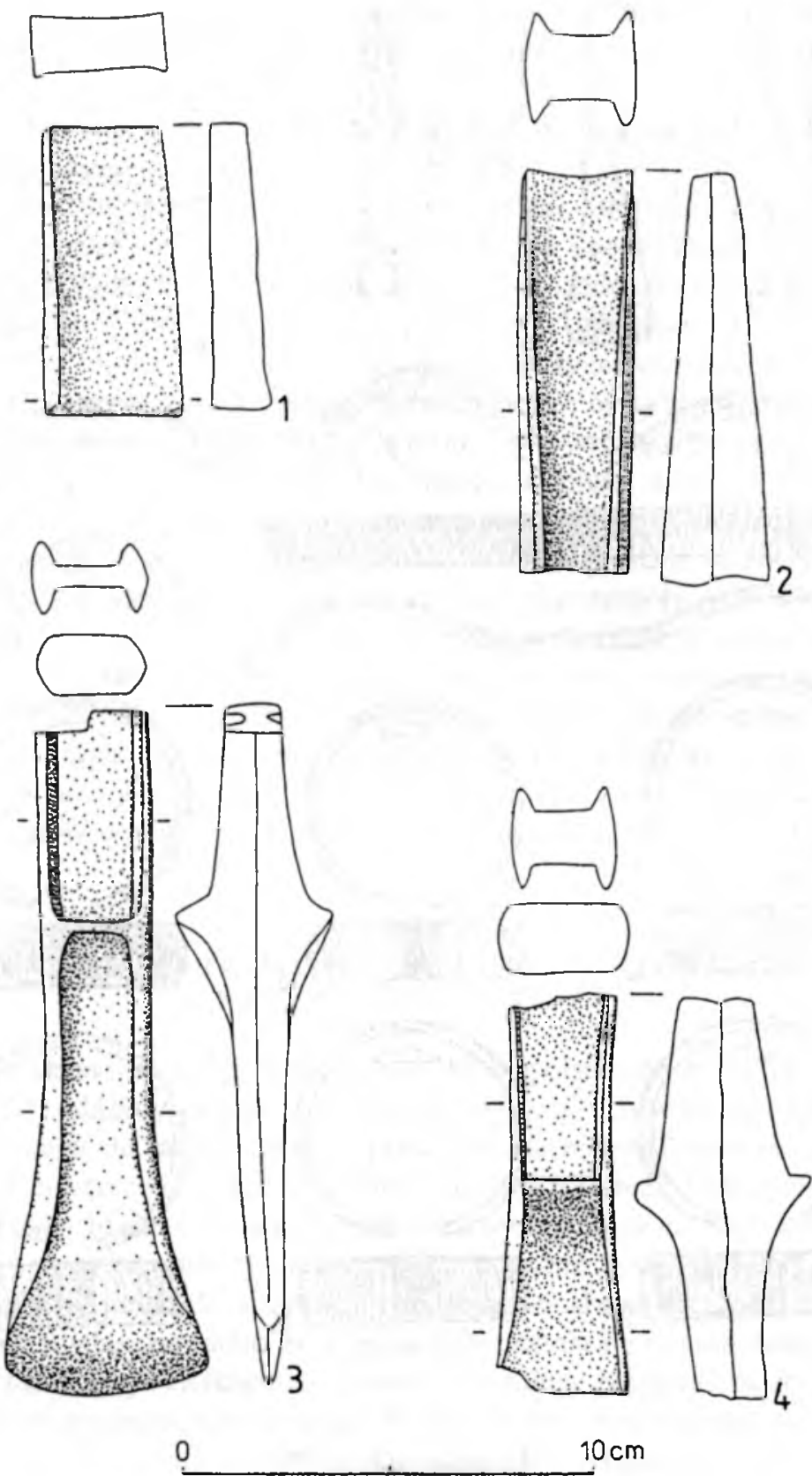

Ryc. 10. Skarb z Międzyrzecza

wg S. Kurnatowskiego (1966)

Fig. 10. Hoard from Międzyrzecz

according to S. Kurnatowski (1966) 

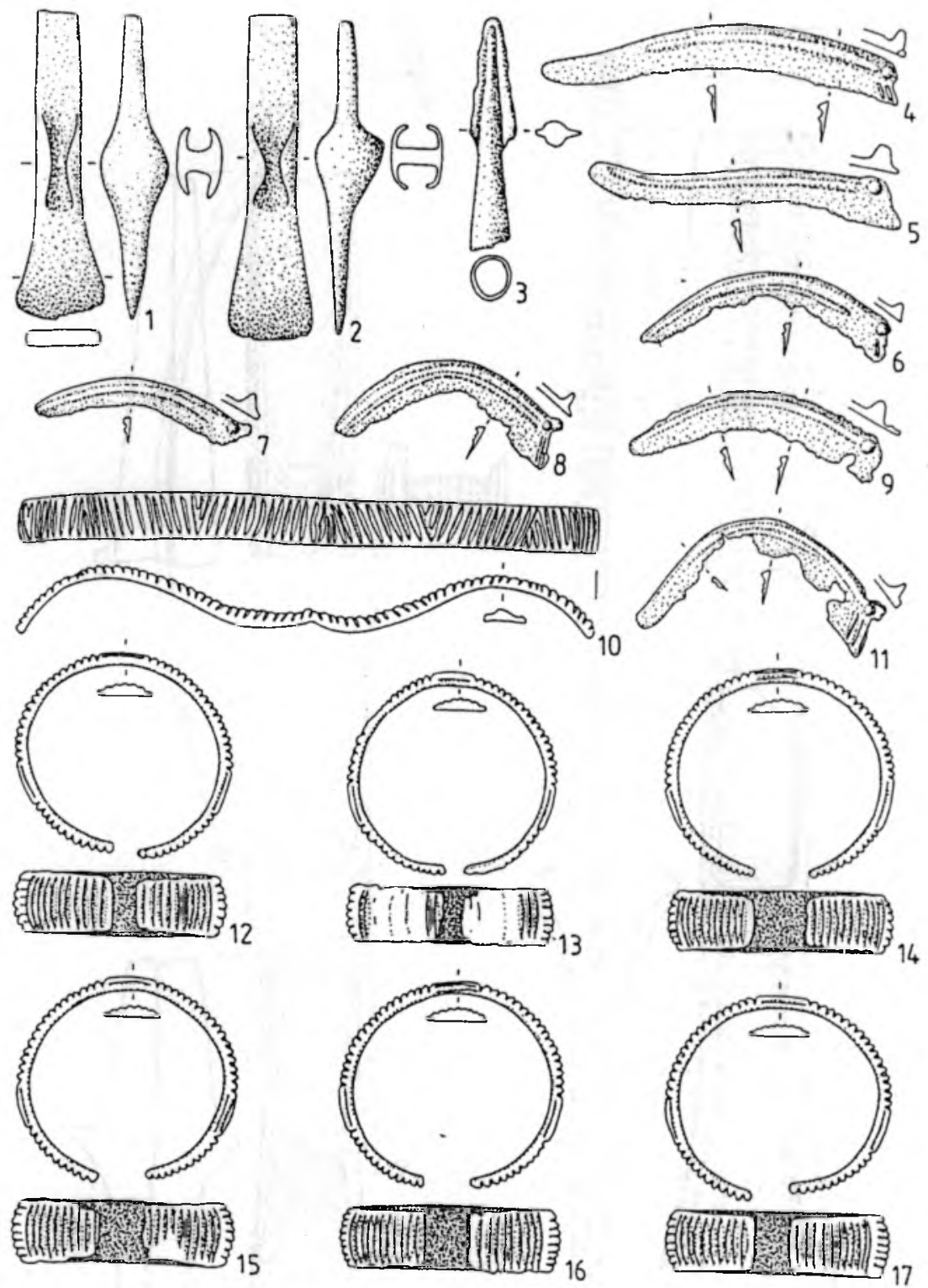

15

0

$10 \mathrm{~cm}$

Ryc. 11. Skarb z Wilenka, pow. Świebodzin wg M. Gedla (1995)

Fig. 11. Hoard from Wilenko, district of Świebodzin according to M. Gedl (1995) 
$\mathrm{Z}$ innych zjawisk kulturowych obserwowalnych w materiale archeologicznym wypada wskazać obecność cmentarzysk kurhanowych na zachodnich rubieżach analizowanego obszaru (Buków, stan. 2 - nr 51, ryc. 8) oraz dużą frekwencję pochówków bezpopielnicowych, nie spotykaną już później na nekropoliach zachodniowielkopolskich.

Scharakteryzowaną wyżej wczesną fazę rozwoju kultury łużyckiej w zachodniej Wielkopolsce można synchronizować z całym III EB i początkami IV EB, a więc z fazami $\mathrm{BD}-\mathrm{HaA}_{1} / \mathrm{HaA}_{2}$ w schemacie chronologii naddunajskiej. Odpowiada ona fazom Kietrz IIb - IIc w południowej części Śląska ${ }^{75}$ oraz fazie 1 i 2 w środkowej części Dolnego Śląska ${ }^{76}$. Kwestią otwartą pozostaje sygnalizowana powyżej możliwość podziału fazy wczesnołużyckiej na dwa mniejsze odcinki: starszy - korelowany z pierwszą połową III EB (BD) i młodszy - umieszczany pomiędzy 2. połową III EB a początkami IV EB $\left(\mathrm{HaA}_{1}-\mathrm{HaA}_{1} / \mathrm{HaA}_{2}\right)$. Odcinek starszy, reprezentowany incydentalnie, wyznaczaja przede wszystkim skarby, w których elementy typowe dla schyłku okresu mogiłowego współwystępuja jeszcze z formami uznawanymi już za wczesnołużyckie. Można doń zaliczyć także nieliczne zespoły grobowe z wczesną ceramiką guzową (guzy typu $C, D_{1}$ i E) spotykaną niekiedy w towarzystwie szpil uchatych typu A. Odcinek młodszy reprezentują materiały uznawane dotąd za typowe dla całego III EB, co oznacza zwykle drugą połowę tego okresu (ceramika zdobiona guzami typu $\mathrm{D}_{2}, \mathrm{D}_{3}$ ) i dla początków IV EB. Ustalenie cezury pomiędzy owymi odcinkami jest trudne, zwłaszcza w przypadku znalezisk gromadnych oraz inwentarzy grobowych, których wyznaczniki chronologiczne nie układają się równolegle.

\section{KULTUROWE I OSADNICZE UWARUNKOWANIA GENEZY KULTURY ŁUŻYCKIEJ W ZACHODNIEJ WIELKOPOLSCE}

Genezę kultury łużyckiej w zachodniej Wielkopolsce i na ziemi lubuskiej łączy się niekiedy z oddziaływaniami grupy sasko-łużyckiej ${ }^{77}$, co w świetle analizy materiału źródłowego nie znajduje obecnie pełnego uzasadnienia. Przede wszystkim brak tutaj charakterystycznych, ,talerzowatych” guzów sasko-łużyckich, dominuje natomiast stylistyka bliska ornamentyce guzowej występującej na Śląsku. W zakresie wytwórczości metalurgicznej obserwuje się podobne tendencje, chociaż zasięgi poszczególnych form są dużo szersze i obejmują niemal całą zachodnią strefę kultury łużyckiej. Wydaje się zatem, że w procesie tworzenia się wczesnołużyckich ugrupowań w zachodniej Wielkopolsce główną rolę należy przypisać raczej społecznościom zamieszkującym tereny Dolnego Śląska. Stamtąd też, zapewne wzdłuż szlaku odrzańskiego, rozchodziły się impulsy kulturowe, które doprowadziły w początkach

\footnotetext{
${ }^{75}$ Gedl 1980 b, s. 88-94.

${ }^{76}$ Gediga 1982, tabl. 1.

${ }^{77}$ Gedl 1974a, s. 40; 1975b, s. 36, $118 ; 1980$ c, s. $83,84$.
} 
III EB (BD) do wykształcenia się pierwszych zespołów w typie pól popielnicowych na ziemi lubuskiej i na zachodnich rubieżach Wielkopolski.

Stanowiska wczesnołużyckie w zachodniej Wielkopolsce wyraźnie koncentrują się w strefie dolnej Obry (Obniżenie Obrzańskie), choć w postaci rozproszonej czytelne są również nad środkowym biegiem tej rzeki, nad dolną Notecią i sporadycznie wzdłuż środkowej Warty (ryc. 2). Osadnictwo układa się przede wszystkim wzdłuż większych arterii wodnych, będących zapewne drogami wewnątrzregionalnej komunikacji, co wydaje się zrozumiałe, zważywszy na zapewne znaczne zalesienie tych terenów $w$ epoce brązu ${ }^{78}$. Trudno obecnie rozstrzygnąć, czy skupiska nadnoteckie powstały równoczasowo $\mathrm{z}$ nadobrzańskimi, czy też nieco później - w wyniku transmisji nowych wzorców kulturowych (akulturacji) bądź migracji niewielkich grup kolonizacyjnych. Istotne jest natomiast określenie stosunku nowo formującej się struktury osadniczej do sieci osadnictwa z okresu poprzedniego, dość słabo - jak to starałem się wykazać wyżej - rozpoznanego. Analiza porównawcza obu map osadniczych (ryc. 1,2) pozwala na pewną korektę wcześniejszych sugestii M. Ge$\mathrm{dla}^{79}$, wedle których zasięgi przestrzenne formacji późnomogiłowych i wczesnołużyckich miałyby się wzajemnie wykluczać. Spostrzeżenie to znajduje potwierdzenie przede wszystkim w odniesieniu do kształtującego się w początkach III EB skupiska międzyrzecko-zbąszyńskiego, zlokalizowanego w strefie Obniżenia Obrzańskiego, gdzie występuje największa liczba wczesnołużyckich cmentarzysk, z dość dobrze datowanymi zespołami. Dla okresu poprzedniego nie zarejestrowano tam takiego nasycenia znaleziskami. Pewną aktywizację osadnictwa daje się również zaobserwować nad dolną Notecią, terenem słabo przedtem penetrowanym przez społeczności starszobrązowe. Trudno natomiast mówić o powstawaniu nowych ekumen w dorzeczu środkowej Warty i Obry, gdzie wyróżnione zostały skupiska: kościanskie i poznańsko-szamotulskie. Tutaj bowiem dostrzegamy ewidentną kontynuację zasiedlenia od starszego okresu epoki brązu, choć charakter niektórych znalezisk zwłaszcza bezkontekstowych, określanych zwykle jako formy wczesnołużyckie może budzić pewne watpliwości zwiazane $\mathrm{z}$ atrybucja kulturową (np. siekierki z prostą piętką typu wielkopolskiego). Równie dyskusyjny pod względem chronologicznym, gdyż balansujący na granicy rozwoju kultury mogiłowej i wczesnołużyckiej, depozyt (zespół zakumulowany) z Radzimia-Maniewa, stan. $4^{80}$, zdaje się jednak poświadczać ciągłość osadniczą w dwóch skrajnych częściach omawianego obszaru, przynajmniej od schyłku II EB.

Przy obecnym stanie źródeł wydaje się, że najbardziej intensywny proces szerzenia się kultury lużyckiej następował od zachodu, z terenów położonych w dorzeczu dolnej Obry, gdzie w początkach III EB (BD) powstało prężne skupisko osadnicze (międzyrzecko-zbąszyńskie). Niewykluczone, że jego geneza łączy się

\footnotetext{
${ }^{78}$ Kurnatowski 1995, s. 6 n.

${ }^{79}$ Gedl 1975a, s. 35.

${ }^{80}$ Kurnatowski 1966, s.163-166; Riemer 1997.
} 
z przybyciem tutaj pewnych grup ludności ze Śląska (wzdłuż Odry i dalej wzdłuż Ołoboku), które nie tylko dokonały kolonizacji słabo dotąd zasiedlonych ekumen nadobrzańskich, ale także doprowadziły do stopniowego przekształcania kultury lokalnych społeczności związanych zapewne z tzw. grupą lubuską późnej kultury unietyckiej (cmentarzysko w Swarzynicach, pow. zielonogórski). Zapewne stamtąd rozchodzily się następnie silne impulsy kulturowe, choć nie sposób wykluczyć także czynnika migracyjnego, działającego $w$ kierunku rozległej doliny Noteci oraz w głąb Pojezierza Poznańskiego, nad Czarną Wodę i Dojcę, a więc do wschodnich rubieży skupiska międzyrzecko-zbąszyńskiego. Jednocześnie aktywnej zmianie kulturowej poddane zostały społeczności egzystujące nad środkową Wartą i Obrą (skupiska osadnicze wokół Poznania, Szamotuł i Kościana), przy czym nie sposób obecnie odpowiedzieć na pytanie, skąd następowała emisja nowych wzorców kulturowych. Prawdopodobna jest zarówno droga wzdłuż Obry ze skupiska międzyrzecko-zbąszyńskiego, jak i bezpośrednio ze Śląska poprzez południową Wielkopolskę ${ }^{81}$.

Prowadzenie szerokiej i skutecznej akcji adaptacyjnej, tak w znaczeniu osadniczym, jak i kulturowym, nie byłoby możliwe bez stałej łączności tych populacji z ośrodkami śląskimi. Podobny mechanizm cechował zapewne pojawianie się pierwszych zespołów popielnicowych na innych obszarach zachodniej strefy kultury łużyckiej (ziemia lubuska), nieco później objętych jej zasięgiem aniżeli Śląsk, Słowacja czy Łużyce ${ }^{82}$. Tym częściowo można by tłumaczyć wytworzenie się w ciagu III EB ogromnych skupisk ceramiki guzowej, ciągnących się wzdłuż dorzecza środkowej Odry ${ }^{83}$. Poza stylem guzowym w ceramice, szeroka integracja strefy nadodrzańskiej, której zachodnia Wielkopolska była częścią w środkowym okresie epoki brązu, przejawiała się także analogicznym zestawem użytkowanych wyrobów brązowych, jak choćby późne formy szpil uchatych typu A i C (odmiana Opatów) oraz szpil z kolbowatą główką (typ Swobnica oraz odmiany Dobrzyca i Trzebnik). Od połowy IH EB $\left(\mathrm{HaA}_{1}\right)$ pojawia się też bardzo charakterystyczny sposób zdobienia bransolet, określany jako styl kanelurowy (ryc. 11). Skarby zawierające takie ozdoby, określane mianem zespołów typu Droszków, poza zachodnią Wielkopolską występują także na Dolnym Śląsku i na Łużycach ${ }^{84}$. Większość zachodniowielkopolskich depozytów datowanych pomiędzy 2. połową III EB a 1. połową IV EB $\left(\mathrm{HaA}_{1}-\mathrm{HaA}_{2}\right)$ charakteryzuje się strukturą inwentarza zbliżoną do zespołów grupy śląskiej. Analiza pozostałych aspektów kultury materialnej fazy wczesnołużyckiej nie pozwala przeprowadzić wyraźnych rozgraniczeń pomiędzy obydwoma regionami z jednym wyjątkiem: są nim groby kurhanowe, dość licznie występujące w pół-

\footnotetext{
${ }^{81}$ Kurnatowski 1995 , ryc. 7.

${ }^{82}$ Gedl 1975b, s. 35-38.

${ }^{83}$ Kwapiński 1985, mapa 3.

${ }^{84}$ Blajer 1990b, s. 20-22, Abb. 9; 1996, s. 93, Karte 3; 1999, s. 126, 127; Kaczmarek 2002, s. 166 ,
} ryc. 66 . 
nocnej części Dolnego Śląska, a na analizowanym obszarze pojawiające się sporadycznie tylko na zachodnich rubieżach; bez wątpienia stanowią one tutaj północne przedłużenie skupiska śląskiego ${ }^{85}$. Pozostałe reguły obrządku pogrzebowego zdają się nie odbiegać zasadniczo od tych, które obserwujemy na innych cmentarzyskach zachodniowielkopolskich. Podobne relacje obserwujemy zresztą przez całą młodszą epokę brązu.

Proces kształtowania się kultury łużyckiej w zachodniej Wielkopolsce, który zakończył się najprawdopodobniej dopiero w 1. połowie IV EB $\left(\mathrm{HaA}_{2}\right)$, doprowadził do przemiany kulturowej przede wszystkim na terenach położonych w pobliżu większych cieków wodnych. Kolonizacja/akulturacja pozostałych ziem przypada na czasy późniejsze, $w$ dobie stabilizacji społeczno-kulturowej nowego systemu, a zarazem jego wewnętrznego zróżnicowania. W przypadku zachodniej Wielkopolski najwymowniejszym odzwierciedleniem owej regionalizacji jest powstanie w poczattkach młodszego okresu epoki brązu stylu uradzkiego w ceramice naczyniowej ${ }^{86}$.

\section{BIBLIOGRAFIA}

\section{A. Wykaz skrótów}

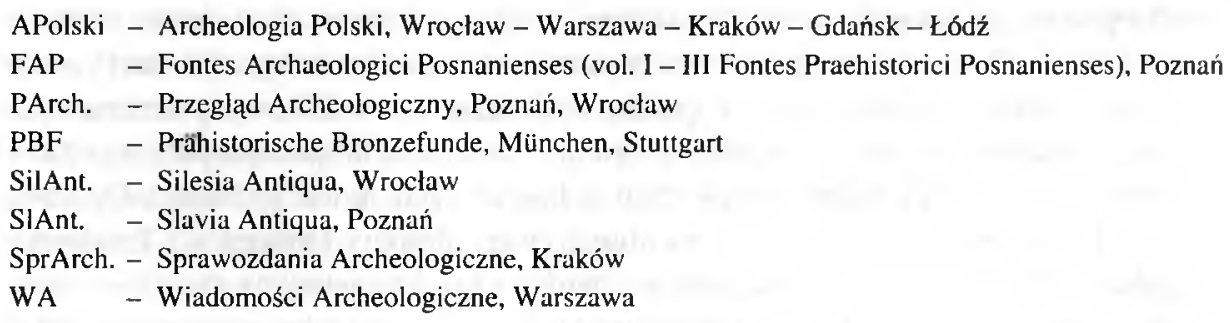

\section{B. Literatura}

B I a j e r W.

1984 Die Arm- und Beinbergen in Polen, PBF, X, 2.

1988 Uwagi o znaleziskach naramienników z tarczkami spiralnymi na ziemiach polskich [Zus. Einige Bemerkungen zum Auftreten der Armringe mit spiralscheiben auf dem polnischen Gebieten], APolski, t. XXXIII, s. 151-164.

1990a Skarby z wczesnej epoki brazu na ziemiach polskich [Zus. Frühbronzezeitliche Hortfunde auf dem polnischen Gebieten], Wroclaw - Warszawa - Kraków - Gdańsk - Łódź.

${ }^{85}$ Malinowski 1962 , s. 10-16, mapa I.

${ }^{86}$ Schneider 1958; Gedl 1975b, s. 118, 119, tabl. XIX: 4-14; Marcinkian 1986, s. 110, 111; Bukowski 1998, s. 21. 
1990b Zur Chronologie der Bronzehortfunde in Polen - frïhe bis mittlere Bronzezeit, .,Zeitschrift für Archäologie", 24, s. 1-26.

1990c Zur Problematik der Hortfunde der Vorlausitzer Kultur, (w:) Beiträge zur Geschichte und Kultur der mitteleuropäischen Bronzezeit. Teil I, Berlin - Nitra, s. 55-65.

1996 Prinzessinnen und Schmiede. Einige Bemerkungen zur regionalen Differenzierung des Ringschmucks in der frühen Phase der Lausitzer Kultur, (w:) Problemy epoki brazu i wczesnej epoki żelaza w Europie Srodkowej. Księga jubileuszowa poświęcona Markowi Gedlowi w sześćdziesiąta rocznice urodzin i czterdziestolecie pracy $w$ Uniwersytecie Jagiellońskim (red. J. Chochorowski), Kraków, s. 83-110.

1999 Skarby ze starszej i środkowej epoki brqzu na ziemiach polskich [Zus. Hortfunde der älteren und mittleren Bronzezeit auf den polnischen Gebieten], Kraków.

Boh m W.

1935 Die altere Bronzezeit in der Mark Brandenburg, Berlin - Leipzig.

Bokin iec A.Z., Czebreszuk J.

1993 Smiardowo i Skrzatusz na nowo odkryte, czyli: czy wyważone drzwi byty otwarte? [Zus. Śmiardowo und Skrzatusz neu entdeckt, oder: war die eingerannte Tür offen?], APolski, t. XXXVIII, s. 123-136.

Brunn W.A. von

1968 Mitteldeutsche Hortfunde der jüngeren Bronzezeit, „Römisch-Germanische Forschungen”, Bd. 29.

Bukowski Z.

1980 W sprawie wczesnych faz epoki brąu w poludniowej strefie Polski, APolski, t. XXV, s. $281-324$.

1983 W sprawie genezy $i$ rozwoju podziatu strefowego ziem polskich w epoce brąu $i$ we wczesnej epoce żelaza [Rés. Á propos de la genèse et du développement zonal des territoires Polonais à l'Âge du Bronze et dans la période ancienne de l'Âge du Fer], SIAnt., t. XXVIII, s. 19-70.

1998 Pomorze w epoce brązu w świetle dalekosiężnych kontaktów wymiennych [Zus. Pommern in der Bronzezeit im Lichte der weitreichenden Tauschkontakte], Gdańsk.

\section{Chudziakowa J.}

1974 Kultura tużycka na terenie międzyrzecza Wishy, Drwęcy i Osy [Zus. Die Lausitzer Kultur im Flussgebiet der Wisła, Drwęca und Osa], Warszawa - Poznań.

Coblenz W.

1952 Grabfunde der Mittelbronzezeit Sachsens, Dresden.

Cofta-B roniewska A., Kosko A.

1982 Historia pierwotna społeczeństw Kujaw [Sum. Prahistory of Cuiavian Societies], Warszawa - Poznań.

Dąbrowski J.

1991 Uwagi o powstawaniu kultur lużyckich [Zus. Bemerkungen zur Entstehung der Lausitzer Kulturen], (w:) Die Anfäge der Urnenfelderkulturen in Europa (red. M. Gedl), Archaeologia Interregionalis, vol. XIII, s. 195-215.

1993 O podstawowych pojęciach chronologii względnej (na przykladzie epoki brazu i wczesnej epoki żelaza) [Zus. Über die Grundbegriffe der relativen Chronologie (am Beispiel der Bronzezeit und frühen Eisenziet)], APolski, t. XXXVIII, z. 2, s. 210-228.

Durczewski D., Śmigielski W.

1965 Materiaty do osadnictwa ludności kultury lużyckiej w Wielkopolsce. Część l [Zus. Materialien der Lausitzer Kultur in Grosspolen (von der mittleren bis zur Latènezeit)], FAP, vol. XVI, s. 139-238. 
1966 Materiaty do osadnictwa ludności kultury lużyckiej w Wielkopolsce. Czesść II [Zus. Materialien der Lausitzer Kultur in Grosspolen (von der mittleren bis zur Latènezeit)], FAP, vol. XVII, s. 65-195.

1970 Materialy do osadnictwa ludności kultury lużyckiej w Wielkopolsce. Część III [Zus. Materialien der Lausitzer Kultur in Grosspolen (von der mittleren bis zur Latènezeit)]. FAP, vol. $\mathrm{XX}, \mathrm{s} .46-105$.

Dy maczewska U.

1963 Cmentarzysko kultury tużyckiej we wsi Plomykowo, pow. Gorzów [Rés. Cimetière de la civilisation lusacienne à Płomykowo, distr. de Gorzów], FAP, vol. XIII, s. 314-317.

Dzi eduszycki W.

1998a Swięty Wojciech, st. 10 (GAZ nr 57) - badania wykopaliskowe, (w:) Archeologiczne badania ratownicze wzdtuż trasy gazociagu tranzytowego, t. I, Ziemia Lubuska (red. R. Mazurowski), Poznań, s. 241-267.

Essen $\mathrm{R}$.

1985 Die Nadeln in Polen II (Mittlere Bronzezeit), PBF, XIII, 9.

Fogel J.

1979 Studia nad uzbrojeniem ludności kultury lużyckiej w dorzeczu Odry $i$ Wisty [Zus. Studien zur Bewaffnung der Bevölkerung der Lausitzer Kultur im Oder- und Weichselgebiet (Angriffswaffe)], Poznan.

1988 Militaria kultury tużyckiej z dorzecza Odry $i$ Wisty (źródta) [Zus. Militaria der Lausitzer Kultur aus dem Flussgebiet von Oder und Weichsel (Quellen)], Poznań.

Gardawski A.

1979a Geneza kultury luzyckiej, (w:) Prahistoria ziem polskich. T. IV. Od środkow'ej epoki brąu do środkowego okresu lateńskiego (red. J. Dąbrowski, Z. Rajewski), Wrocław - Warszawa - Kraków - Gdańsk, s. 47-49.

1979b Najstarsza kultura lużycka w Wielkopolsce wschodniej i środkowej, (w:) Prahistoria ziem polskich. T. IV. Od środkowej epoki brazu do środkowego okresu lateńskiego (red. J. Dąbrowski, Z. Rajewski), Wrocław - Warszawa - Kraków - Gdańsk, s. 63-64.

1979c Grupy z ceramikq guzowq na Dolnym Ślasku, w zachodniej Wielkopolsce i nad góma Nysa, (w:) Prahistoria ziem polskich. T. IV. Od środkowej epoki brazu do środkowego okresu lateńskiego (red. J. Dąbrowski, Z. Rajewski), Wrocław - Warszawa - Kraków - Gdańsk, s. 64-69.

Gediga B.

1967 Plemiona kultury lużyckiej w epoce brqzu na Ślqsku środkowym [Sum. Tribes with Lusatian Culture in middle Silesia in the Bronze Age], Wrocław - Warszawa - Kraków.

1977 Zagadnienie genezy kultury tuzyckiej na terenach Nadodrza [Zus. Zur Frage des Ursprungs der Lausitzer Kultur im Odergebiet], (w:) Geneza kultury tużyckiej na terenie Nadodrza (red. B. Gediga), Wroctaw, s. 7-16.

1978 Starszy okres epoki brazu na ziemiach polskich w zasięgu kultury „przedlużyckiej”, (w:) Prahistoria ziem polskich. T. III. Wczesna epoka brqzu (red. A. Gardawski, J. Kowalczyk), Wrocław - Warszawa - Kraków - Gdańsk, s. 137-172.

1982 Zagadnienia periodyzacji okresu rozwoju kultury lużyckiej w świetle kontakıów z Poludniem [Zus. Die Fragen der Periodisierung der Lausitzer Kultur im Licht der Verbindungen mit Süden], (w:) Potudniowa strefa kultury lużckiej i powiqzania tej kultury z Poludniem (red. M. Gedl), Kraków - Przemyśl, s. 49-58.

1991 Zagadnienie ksztaltowania się cech lużyckich pól popielnicowych [Zus. Zur Frage der Herausbildung von Merkmalen der Lausitzer Urnenfelderkultur], (w:) Die Anfänge der Urnenfelderkulturen in Europa (red. M. Gedl), Archaeologia Interregionalis, vol. XIII, s. 17-26. 
Ged I M.

1967 Studia nad wczesna faza kultury lużyckiej w środkowej i wschodniej Polsce [Sum. Study on the early phase of Lusatian Culture in middle and eastern Poland], APolski, t. XII, s. 281-318.

1974a Anfänge der Lausitzer Kultur, (w:) Studien zur Lausitzer Kultur, Zeszyty Naukowe UJ, Prace Archeologiczne, z. 18, Kraków, s. 7-55.

1974b Początki rozwoju kultury lużyckiej na Górnym Śląsku [Zus. Die Anfănge der Entwicklung der Lausitzer Kultur in Oberschlesien], APolski. t. XIX, s. 147-176.

1975a Kultura przedlużycka [Rés. La culture Prèlusacienne], Wrocław - Warszawa - Kraków Gdańsk.

1975b Kultura tużycka, Kraków.

1977 Wczesna faza ślaskiej i górnoślasko-matopolskiej grupy kultury tużyckiej [Zus. Frühe Phase der schlesischen und oberschlesisch-kleinpolnischen Gruppe der Lausitzer Kultur], (w:) Geneza kultury tużyckiej na terenie Nadodrza (red. B. Gediga), Wrocław, s. 35-59.

1979 Stufengliederung und Chronologie des Gräberfeldes der Lausitzer Kultur in Kietrz, Zeszyty Naukowe UJ, Prace Archeologiczne, z. 27.

1980a Die Dolche und Stabdolche in Polen, PBF, VI, 4.

1980b Studia nad periodyzacja kultury tużyckiej w poludniowej części Ślq̨ska [Zus. Studien zur Periodisierung der Lausitzer Kultur im südlichen Teil Schlesiens], APolski, t. XXV, s. 79-129.

1980c Zróżnicowanie kulturowe w strefie zaliczanej do „kultury tużyckiej” [Zus. Kulturdifferenzierung in der „Lausitzer Kultur” zugewiesen zone], (w:) Zróżnicowanie wewnętrzne kultury tużyckiej (red. M. Gedl), Kraków, s. 78-94.

1982 Uwagi dyskusyjne o wczesnym okresie epoki brazu w zachodniej cześci Polski, APolski, t. XXVI, s. 419-428.

1983 Die Nadeln in Polen I (Frühe und altere Bronzezeit), PBF, XIII, 7.

1989 Grupy lokalne w obrębie kultury tużyckiej, (w:) Pradzieje ziem polskich. T. 1-2 (red. J. Kmieciński), Warszawa - Łódź, s. 607-646.

1991 Bemerkungen über Anfänge der frühen Lausitzer Kultur in Schlesien, (w:) Die Anfange der Umenfelderkulturen in Europa (red. M. Gedl), Warszawa, s. 89-102.

1992 Die Vorlausitzer Kultur, PBF, XXI, 2.

1995 Die Sicheln in Polen, PBF, XVIII, 4.

J a cob-Friesen G.

1967 Bronzezeitlichen Lanzenspitzen Norddeutschlands und Skandinavien, Hildesheim.

Jasnosz S.

1953 Cmentarzysko kultury tużyckiej w Borku, pow. Gorzów, Ziemia Lubuska, [Rés. Un cimetière de la civilisation lusacienne à Borek, distr. de Gorzów], FAP, vol. III, s. 85-97.

1982 Materiaty $i$ studia do dziejów osadnictwa starożytnego $i$ wczesnośredniowiecznego Ziemi Obornicko-Rogozińskiej (część l) [Sum. Materials and studies to the prehistoric and early medieval human occupation in the district of Oborniki - Rogoźno, Part I], FAP, vol. XXXI, s. 1-144.

1983 Materiaty $i$ studia do dziejów osadnictwa starożytnego $i$ wczesnośredniowiecznego Ziemi Obormicko-Rogozińskiej (część 2) [Sum. Materials and studies to the prehistoric and early medieval human occupation in the district of Oborniki-Rogoźno, Part II], FAP, vol. XXXII, s. 105-155.

1984 Materiaty $i$ studia do dziejów osadnictwa starożytnego i wczesnośredniowiecznego Ziemi Obomicko-Rogozińskiej (część III) [Sum. Materials and studies to the prehistoric and early medieval human occupation in the district of Oborniki-Rogoźno, Part III], FAP, vol. XXXIII, s. 55-166. 
Kaczmarek $M$.

2002 Zachodniowielkopolskie społeczności kultury tużyckiej w epoce brazu [Sum. Communities of the Lusatian Culture from western Wielkopolska in the Bronze Age], Poznan.

Kleemann $O$.

1977 Die mittlere Bronzezeit in Schlesien (1939), „Bonner Hefte zur Vorgeschichte”, Nr. 12/13.

Kłosińska E.

1992a Analiza osadnicza pienwszych okresów epoki brazu w dorzeczu Warty w aspekcie sytuacji kulturowej [Zus. Analyse des Siedlungswesens im Wartaflussgebiet im Hinsicht auf die Kultursituation], PArch, t. 39, s. 87-100.

1992b Z badań nad osadnictwem dorzecza Warty w starszym okresie epoki brazu [Zus. Aus den Forschungen über die Besiedlung des Warthegebietes in älteren Bronzezeitperiode]. (w:) Problemy badań nad osadnictwem pradziejowym, Wrocław - Warszawa - Kraków, s. 143-160.

1997 Starszy okres epoki brąu w dorzeczu Warty [Zus. Die ältere Periode der Bronzezeit im Warthegebiet], Wrocław.

Kn a powska-Mikola jcz y kowa A.

1957 Wczesny okres epoki brazu w Wielkopolsce [Rés. La I Ire periode de l'âge du Bronze en Grande Pologne], FAP, vol. VII, s. 31-115.

Kołodziejski A.

1965 Cmentarzysko cialopalne w Jasieńcu, pow. Międzyrzecz Wlkp. [Zus. Das Urnenfeld der Lausitzer Kultur in Jasieniec, Kreis Międzyrzecz WIkp.], „Materiały Komisji Archeologicznej", z. 1, s. 113-126.

1971 Kultura tużycka na Ziemi Lubuskiej, (w:) Materiaty do prahistorii ziem polskich, Cz. IV, zeszyt 1. Materiaty kultury tużyckiej i kultury pomorskiej (red. Z. Rajewski), Warszawa, s. $49-110$.

1980 Zróżnicowanie kultury lużyckiej na Środkowym Nadodrzu [Zus. Differenzierung der Lausitzer Kultur auf dem Mittelodergebiet], (w:) Zróżnicowanie wewnętrzne kultury tużyckiej (red. M. Gedl), Kraków, s. 95-111.

Kostrzewski J.

1933 I, Il i IIl okres epoki bronzowej w Polsce [Rés. L'âge du Bronze I, II et III en Pologne], PArch., t. IV, s. 1-35.

1948 Od mezolitu do okresu wędrówek ludów, (w:) S. Krukowski, J. Kostrzewski, R. Jakimowicz, Prehistoria ziem polskich. Encyklopedia Polska, t. 4, cz. 1, dz. V, Warszawa - Kraków - Łódź - Poznań - Zakopane, s. 118-448.

1949 Pradzieje Polski, Poznań.

1955 Wielkopolska w pradziejach, wyd. III, Warszawa - Wroclaw.

1963 Siekierki z piętka typu wielkopolskiego [Sum. Palstaves of the Great Polish type], „Prace i Materiały Muzeum Archeologicznego i Etnograficznego w Lodzi”, Nr 9, s. 5-11.

Kostrzewski J., Chmielewski W., Jażdżewski K.

1965 Pradzieje Polski [Rés. Préhistoire de la Pologne], Wrocław - Warszawa - Kraków.

Kowiańska-Pi a s z y kowa M., Kurnatowski S.

1954 Kurhan kultury unieryckiej w Lękach Matych, pow. Kościan [Sum. A barrow of the Unetician Culture in Łęki Małe in distr. of Kościan], FAP, vol. IV, s. 43-76.

Krzyszowski A.

1998 Swięty Wojciech, st. 10 (GAZ nr 57) - badania wykopaliskowe cmentarzyska kultury tużyckiej, (w:) Archeologiczne badania ratownicze wzdtuż trasy gazociagu tranzytowego. T. I. Ziemia Lubuska (red. R. Mazurowski), Poznań, s. 199-240. 
Kurnatowski S.

1963 Uwagi o ksztattowaniu się stref zasiedlenia dorzecza Obry w czasie od środkowego okresu epoki brazu do późnego średniowiecza [Sum. Notes of formation of settlement zones of the Obra basin in the period lasting from the middle of the Bronze Age till late Middle Ages], APolski, t. VIII, s. 181-221.

1966 Materialy do środkowego okresu epoki brazowej w Wielkopolsce [Rés. Matériaux contribuant à l'étude de la période moyenne de l'âge du Bronze en Grande Pologne], PArch., t. XVII, s. 122-201.

1995 Przemiany osadnicze w procesie ksztaltowania się Wielkopolski jako regionu historycznego [Zus. Besiedlungswandlungen bei dem Prozess der Gestaltung Grosspolens als eine historische Region], SIAnt, t. XXXV, s. 3-45.

K wapińs k i M.

1974a Kurhan z III okresu epoki braqu w Bukowie, pow. Sulechów [Sum. A barrow from period III of the Bronze Age in Buków, distr. of Sulechów], FAP, vol. XXIV, s. 12-16.

1974b Groby z III okresu epoki brazu ze Swarzynic, pow. Sulechów [Sum. Graves from period III of the Bronze Age at Swarzynice, distr. of Sulechów], FAP, vol. XXIV, s. 17-20.

1974c Z problematyki klasyfikacji kulturowej wczesnej epoki brazu na Ziemi Lubuskiej, „Zielonogórskie Zeszyty Muzealne", t. 4, s. 25-39.

1985 Analiza taksonomiczna kultur starszej polowy epoki brąu w dorzeczu środkowej Odry, Gdańsk.

1986 Uwagi o genezie grobów kurhanowych ludności kultury tużyckiej w dorzeczu Odry, „Rocznik Lubuski", t. 14, s. 119-150.

Lipińska A.

1961 Cmentarzysko kultury tużyckiej z przelomu III i IV okr. epoki brazu w Kotowie pow. Nowy Tomyśl [Rés. Un cimetière de la civilisation lusacienne à Kotowo, distr. de Nowy Tomyśl], FAP, vol. XII, s. 48-55.

L ü cke J.

1997 Zion, Kr. Züllichau-Schwiebus, Prov. Brandenburg (Wilenko, Gm. Szczaniec, Woj. Zielona Góra, Polen), (w:) Gaben an die Götter. Schätze der Bronzezeit Europas (red. A. Hänsel, B. Hänsel), Berlin, s. 230-232.

Machnik J.

1978 Kultury wczesnego okresu epoki brazu na ziemiach polskich. Krag kultury unietyckiej, (w:) Prahistoria ziem polskich. T. III. Wczesna epoka brazu (red. A. Gardawski, J. Kowalczyk), Wroclaw - Warszawa - Kraków - Gdańsk, s. 81-117.

Malinowski T.

1961 Katalog cmentarzysk ludności kultury lużyckiej w Polsce, t. I-II, Warszawa.

1962 Obrzadek pogrzebowy ludności kultury lużyckiej w Polsce [Rés. Le rite funéraire chez la population civilisation lusacienne en Pologne], PArch, t. 14, s. 5-135.

Marcinkian A.

1975 Wczesnolużyckie cmentarzysko cialopalne w Swarzynicach, pow. Sulechów [Sum. An early Lusatian cemetery at Swarzynice, Sulechów district], WA, t. XL, s. 317-331.

1976 Międzyrzecz-Obrzyce, woj. Gorzów Wielkopolski, SilAnt., t. 18, s. 298-299.

1986 Z badań nad epokq brazu i wczesnq epokq żelaza na Ziemi Lubuskiej, „Rocznik Lubuski”, t. 14, s. $103-118$.

Aierzwiński A.

1994 Przemiany osadnicze społeczności kultury lużyckiej na Ślqsku [Zus. Die Siedlungswandlungen bei den Gesellschaften der Lausitzer Kultur in Schlesien], Wrocław. 
Ostoja-Zagórski J.

1974 Zespót osadniczy ludności kultury „tużyckiej” z Smolna Wielkiego, pow. Sulechów [Sum. A settlement-complex of the Lusatian Culture at Smolno Wielkie, distr. of Sulechów], FAP, vol. XXIV, s. 33-47.

1977 Przemiany osadnicze $i$ gospodarcze we wczesnych fazach rozwoju kultury tużyckiej w Polsce zachodniej [Zus. Umwaldungen in der Besiedlung und Wirtschaft in den Frühstufen der „Lausitzer" Kultur in Westpolen], (w:) Geneza kultury łuzyckiej na terenie Nadodrza (red. B. Gediga), Wrocław, s. 161-187.

P i e c z y ński Z.

1970 Sprawozdanie z prac wykopaliskowych na osadzie z Il okresu epoki brqzu w Bruszczewie, pow. Kościan, stan. 5 [Zus. Grabungen auf der frühbronzezeitlichen Siedlung in Bruszczewo, Kr. Kościan, Fundstelle 5], FAP, vol. XX, s. 268-27l.

Posern-Zieliński A.

1993 Etnologiczna interpretacja procesów akulturacji [Zus. Ethnologische Interpretation der Akkulturationsprozesse], „Folia Praehistorica Posnaniensia”, t. V, s. 37-53.

Rie mer $P$.

1997 Radzim, Kr. Obonik, Prov. Posen (Radzim, Gm. Obomiki, woj. Poznań, Polen), (w:) Gaben an die Götter. Schätze der Bronzezeit Europas (red. A. Hänsel, B. Hänsel), Berlin, s. 178.

Sarnowska W.

1969 Kultura unietycka w Polsce [Sum. The Unietic Culture in Poland]. Wrocław - Warszawa Kraków.

Schäfer K.

1987 Die Schmirtenauer Kultur. Zur Ordnung der frïhen Bronzezeit im Netze-Warthe-Raum, „Bonner Hefte zur Vorgeschichte“, 23, Bonn.

Schneider J.

1958 Die Keramik des Aurither Stils westlich der Oder, (w:) Studien zur Lausitzer Kultur, Leipzig, s. 5-70.

Szafrański W.

1955 Skarby brazowe z epoki wspólnoty pierwotnej (IV i V okres epoki brqzowej) w Wielkopolsce [Rés. Les trésors de Bronze de l'époque de la communauté primitive (IV-V ${ }^{e}$ période de l'âge du Bronze) en Grande Pologne], Warszawa - Wrocław.

Szpunar A.

1987 Die Beile in Polen I (Flachbeile, Randleistenbeile, Randleistenmeissel), PBF, IX, 16.

Śm i g i ls ki W.

1965a Materiaty z cmentarzyska ludności kultury lużyckiej w Świętym Wojciechu, pow. Międzyrzecz, „Materialy Komisji Archeologicznej”, z. 1, s. 79-104.

1965b Cmentarzysko ludności kultury tużyckiej w Porębie pow. Międzyrzecz, „Materiały Komisji Archeologicznej", z. 1, s. 157-167.

Weige I M.

1893 Bronzefund von Mariendorf, Kr. Filehne, Prov. Posen, „Nachrichten über Deutsche Alterthumsfunde", IV. Jg., s. 65-66.

Wierzbicki J.

1992 [rec.] Klaus Schäfer: Die Schmirtenauer Kultur. Zur Ordnung der frühen Bronzezeit im Netze-Warthe-Raum, Bonner Hefte zur Vorgeschichte, Nr. 23, Bonn 1987, 247 stron, 81 tablic, fotografii i map, FAP, vol. 37, s. 111-114.

W i k lak H.

1963 Poczqlki kultury tużyckiej w Polsce środkowej [Sum. The origin of the Lusatian Culture in central Poland], Łódź 


\title{
ON THE STUDIES OF THE BEGINNINGS OF THE LUSATIAN CULTURE IN WESTERN WIELKOPOLSKA
}

\author{
S u m m ary
}

Emergence of the early Lusatian culture in western Wielkopolska has to be linked with influence of communities from Lower Silesia. It is from where the impulses radiated, probably along the Odra river, that led to the emergence of early assemblages of the Urnfield culture in western Wielkopolska and the Lubusz Lands. The early "Lusatian" sites in western Wielkopolska are concentrated in the area of the lower Obra river, albeit there are also scattered in the middle part of the Obra valley, the lower Notec river, and occasionally in the middle part of the Warta river (fig. 2). A vast majority of settlements was located on slopes and edges of larger river valleys that were probably used for interregional communication. This seems to be understandable taking into account considerable afforestation of the territories in the Bronze Age.

Archaeological evidence makes us claim that the most dynamic spatial development of the Lusatian culture existed in western part of the studied region, that is in the area of the lower Obra river where the largest settlement concentration, namely the Międzyrzecz-Zbąszyń center, was created at this time. One cannot exclude here a migration of small groups from Silesia, which supposedly colonized previously poorly inhabited areas around the Obra river and then along the Ołobok river. In a long run it contributed to acculturation of descendants of local communities that are to be linked with so-called Lubusz group of the Unêtice culture (cemetery at Swarzynice, Zielona Gora commune). It is probably from this area that strong cultural impulses radiated, however one cannot exclude a migration toward the wide Noteć valley and then to the Poznan lake district, at the Czarna Woda and Dojca rivers, that is to say to the eastern outskirts of the Międzyrzecz-Zbąszyń agglomeration. At the same time, local communities living at the middle Warta and Obra rivers (settlement agglomerations around Poznań, Szamotuły, and Kościan) were exposed to intense culture change. However, it is impossible to reconstruct a route through which these new culture patterns infiltrated into western Wielkopolska. This might have been either from the Międzyrzecz-Zbąszyń agglomeration or alternatively directly from Silesia through southern Wielkopolska.

An intensive and efficient adaptation, both with regard to the settlement system as well as culture, might not have been possible without close links with Silesian centers. A very similar mechanism led probably to the emergence of the early Umfield assemblages in other territories of western zone of the Lusatian culture (the Lubusz Lands), that found themselves under this influence somehow later than Silesia, Slovakia or the Lusatian lands. This might explain the emergence of vast concentrations of the knobbed pottery along the middle Odra valley in phase III of the Bronze Age. Besides knobbed pottery, a cultural integration of the Odra region, of which western Wielkopolska was part in the middle Bronze Age, was also manifested in identical set of exploited bronze goods.

The process of formation of the Lusatian culture in western Wielkopolska, which was probably completed only in the first half of phase IV of the Bronze Age (HaA2), led to the culture transformation first of all of the areas located around larger river valleys. Colonization and/or acculturation of remaining areas took place later in the period of social and cultural stabilization of the new system, which at the same was being differentiated. The most significant manifestation of this regionalization in western Wielkopolska is the emergence of the Urad style of pottery in the late phase of the Bronze Age.

Translated by Arkadiusz Marciniak 